\title{
Atmospheric peroxyacetyl nitrate (PAN): a global budget and source attribution
}

\author{
E. V. Fischer ${ }^{1}$, D. J. Jacob ${ }^{2}$, R. M. Yantosca ${ }^{2}$, M. P. Sulprizio ${ }^{2}$, D. B. Millet ${ }^{3}$, J. Mao ${ }^{4}$, F. Paulot ${ }^{1}$, H. B. Singh ${ }^{5}$, \\ A. Roiger $^{6}$, L. Ries ${ }^{7}$, R.W. Talbot ${ }^{8}$, K. Dzepina ${ }^{9}$, and S. Pandey Deolal ${ }^{10}$ \\ ${ }^{1}$ Department of Atmospheric Science, Colorado State University, Fort Collins, CO, USA \\ ${ }^{2}$ School of Engineering and Applied Sciences, Harvard University, Cambridge, MA, USA \\ ${ }^{3}$ Department of Soil, Water and Climate, University of Minnesota, St. Paul, MN, USA \\ ${ }^{4}$ Princeton University, GFDL, Princeton, NJ, USA \\ ${ }^{5}$ NASA Ames Research Center, Moffett Field, CA, USA \\ ${ }^{6}$ Institut für Physik der Atmosphäre, Deutsches Zentrum für Luft- und Raumfahrt (DLR), Oberpfaffenhofen, Germany \\ ${ }^{7}$ Department of Earth and Atmospheric Sciences, University of Houston, Houston, TX, USA \\ ${ }^{8}$ Federal Environment Agency, GAW Global Station Zugspitze/Hohenpeissenberg, Zugspitze, Germany \\ ${ }^{9}$ Department of Chemistry, Michigan Technological University, Houghton, MI, USA \\ ${ }^{10}$ Bluesign Technologies AG, St. Gallen, Switzerland
}

Correspondence to: E. V. Fischer (evf@atmos.colostate.edu)

Received: 25 August 2013 - Published in Atmos. Chem. Phys. Discuss.: 15 October 2013

Revised: 18 January 2014 - Accepted: 30 January 2014 - Published: 14 March 2014

\begin{abstract}
Peroxyacetyl nitrate (PAN) formed in the atmospheric oxidation of non-methane volatile organic compounds (NMVOCs) is the principal tropospheric reservoir for nitrogen oxide radicals $\left(\mathrm{NO}_{\mathrm{x}}=\mathrm{NO}+\mathrm{NO}_{2}\right)$. PAN enables the transport and release of $\mathrm{NO}_{\mathrm{x}}$ to the remote troposphere with major implications for the global distributions of ozone and $\mathrm{OH}$, the main tropospheric oxidants. Simulation of PAN is a challenge for global models because of the dependence of PAN on vertical transport as well as complex and uncertain NMVOC sources and chemistry. Here we use an improved representation of NMVOCs in a global 3-D chemical transport model (GEOS-Chem) and show that it can simulate PAN observations from aircraft campaigns worldwide. The immediate carbonyl precursors for PAN formation include acetaldehyde ( $44 \%$ of the global source), methylglyoxal $(30 \%)$, acetone $(7 \%)$, and a suite of other isoprene and terpene oxidation products (19\%). A diversity of NMVOC emissions is responsible for PAN formation globally including isoprene $(37 \%)$ and alkanes $(14 \%)$. Anthropogenic sources are dominant in the extratropical Northern Hemisphere outside the growing season. Open fires appear to play little role except at high northern latitudes in spring, although results are very sensitive to plume chemistry and plume rise.
\end{abstract}

Lightning $\mathrm{NO}_{\mathrm{x}}$ is the dominant contributor to the observed PAN maximum in the free troposphere over the South Atlantic.

\section{Introduction}

Peroxyacetic nitric anhydride $\left(\mathrm{CH}_{3} \mathrm{COO}_{2} \mathrm{NO}_{2}\right)$, commonly known by its misnomer peroxyacetyl nitrate (PAN), is the principal tropospheric reservoir species for nitrogen oxide radicals $\left(\mathrm{NO}_{\mathrm{x}}=\mathrm{NO}+\mathrm{NO}_{2}\right)$ with important implications for the production of tropospheric ozone $\left(\mathrm{O}_{3}\right)$ and the hydroxyl radical $\mathrm{OH}$ (the main atmospheric oxidant) (Singh and Hanst, 1981). PAN is formed by oxidation of non-methane volatile organic compounds (NMVOCs) in the presence of $\mathrm{NO}_{\mathrm{x}}$. NMVOCs and $\mathrm{NO}_{\mathrm{x}}$ have both natural and anthropogenic sources. Fossil fuel combustion is the principal $\mathrm{NO}_{\mathrm{x}}$ source, with additional contributions from biomass burning, lightning and soils (van der A et al., 2008). The organic side of PAN formation involves many stages of NMVOC oxidation. Most NMVOCs can serve as PAN precursors, but the yields vary widely (Roberts, 2007). 
PAN enables the long-range transport of $\mathrm{NO}_{\mathrm{x}}$ at cold temperatures, and PAN decomposition releases $\mathrm{NO}_{\mathrm{x}}$ in the remote troposphere where it is most efficient at producing $\mathrm{O}_{3}$ and $\mathrm{OH}$ (Singh and Hanst, 1981; Hudman et al., 2004; Fischer et al., 2010; Singh, 1987). $\mathrm{NO}_{\mathrm{x}}$ abundance controls the balance of $\mathrm{O}_{3}$ production and destruction. Without PAN formation the distributions of tropospheric $\mathrm{NO}_{\mathrm{x}}, \mathrm{O}_{3}$ and $\mathrm{OH}$ would be very different, with higher values in $\mathrm{NO}_{\mathrm{x}}$ source regions and lower values in the remote troposphere (Kasibhatla et al., 1993; Moxim et al., 1996; Wang et al., 1998a). PAN chemistry can also be important for oxidant formation on a regional scale. In polluted environments, PAN formation is a sink for both $\mathrm{NO}_{\mathrm{x}}$ and hydrogen oxide radicals $\left(\mathrm{HO}_{\mathrm{x}}\right)$. Observations show that $\mathrm{O}_{3}$ concentrations increase when temperature increases, and this has been in part related to PAN thermal instability (Sillman and Samson, 1995). Observations also show that the production of PAN becomes more efficient relative to $\mathrm{O}_{3}$ in highly polluted air masses (Roberts et al., 1995). Thus a comprehensive understanding of PAN is needed to understand oxidant distributions on a spectrum of scales.

A large body of PAN observations worldwide has accumulated over the years, including in particular from aircraft platforms and mountaintop sites. There have also been recent retrievals of PAN concentrations in the upper troposphere (UT) from satellites (Glatthor et al., 2007; Tereszchuk et al., 2013). Concentrations vary from pptv levels in warm remote locations such as tropical oceans to ppbv levels in polluted source regions. Despite the relatively large database of measurements compared to other photochemical indicators, simulation of PAN in global chemical transport models (CTMs) has been a difficult challenge because of the complexity of PAN chemistry. Recent model intercomparisons show very large difference among themselves and with observations in many regions of the atmosphere (Thakur et al., 1999; Singh et al., 2007; von Kuhlmann et al., 2003; Sudo et al., 2002), but confirm the very important role for PAN in sustaining $\mathrm{O}_{3}$ production in remote air (Zhang et al., 2008; Hudman et al., 2004).

Here we exploit a worldwide collection of PAN observations to improve the PAN simulation in the GEOS-Chem (Goddard Earth Observing System) CTM, which has been used extensively in global studies of tropospheric oxidants (Bey et al., 2001; Sauvage et al., 2007; Murray et al., 2012). The earliest global models that included PAN chemistry (Kasibhatla et al., 1993; Moxim et al., 1996) relied on highly simplified NMVOC budgets. Our improvements involve new treatments of NMVOC sources and chemistry, a well-known weakness even in current CTMs (Williams et al., 2013; Ito et al., 2007). Our new simulation, which captures the major features of the existing observations, affords a new opportunity to understand the factors driving the global PAN distribution and the essential chemistry that needs to be described. A detailed analysis of how PAN shapes the global distributions of the atmospheric oxidants and nitrogen deposition will be the focus of a subsequent paper.

\section{Model description}

We use the GEOS-Chem global 3-D CTM including detailed ozone- $\mathrm{NO}_{\mathrm{x}}-\mathrm{VOC}$-aerosol chemistry (version 9.01.01, www.geos-chem.org) with significant modifications as described below.

\subsection{Chemistry}

GEOS-Chem uses a chemical scheme originally described by Horowitz et al. (1998) and Bey et al. (2001), with recent updates outlined in Mao et al. (2010). Following Marais et al. (2012) we have updated the rate coefficients for the reactions of $\mathrm{HO}_{2}$ with the $>\mathrm{C}_{2}$ peroxy radicals to Eq. (iv) in Saunders et al. (2003). We also include nighttime reactions of organic peroxy radicals with $\mathrm{NO}_{3}$ following Stone et al. (2013). To implement the Stone et al. (2013) nighttime chemistry, we went through each of the $\mathrm{RO}_{2}+\mathrm{NO}$ reactions in the GEOS-Chem chemical mechanism, copied each of these reactions, and changed the $\mathrm{RO}_{2}$ reactants to react with $\mathrm{NO}_{3}$ rather than NO. The Master Chemical Mechanism (MCM) considers three different reactions rates for this class, one for $\mathrm{CH}_{3} \mathrm{O}_{2}$, one for $\mathrm{RC}(\mathrm{O}) \mathrm{O}_{2}$ and one for all other $\mathrm{RO}_{2}$. There is no temperature dependence included, and all products are assumed to be the same as the corresponding reaction of the $\mathrm{RO}_{2}$ radical with $\mathrm{NO}$ (Bloss et al., 2005). We replaced the isoprene chemical mechanism with one based on Paulot et al. (2009a, b), as described by Mao et al. (2013b).

PAN is produced reversibly by reaction of the peroxyacetyl (PA) radical $\mathrm{CH}_{3} \mathrm{C}(\mathrm{O}) \mathrm{OO}$ with $\mathrm{NO}_{2}$ :

$\mathrm{CH}_{3} \mathrm{C}(\mathrm{O}) \mathrm{OO}+\mathrm{NO}_{2}+M \rightleftarrows \mathrm{PAN}+M$,

where $M$ is a third body (typically $\mathrm{N}_{2}$ or $\mathrm{O}_{2}$ ). The dominant sources of $\mathrm{CH}_{3} \mathrm{C}(\mathrm{O}) \mathrm{OO}$ are the oxidation of acetaldehyde $\left(\mathrm{CH}_{3} \mathrm{CHO}\right)$ and the photolysis of acetone $\left(\mathrm{CH}_{3} \mathrm{C}(\mathrm{O}) \mathrm{CH}_{3}\right)$ and methylglyoxal $\left(\mathrm{CH}_{3} \mathrm{COCHO}\right)$ :

$$
\begin{aligned}
& \mathrm{CH}_{3} \mathrm{CHO}+\mathrm{OH} \stackrel{\mathrm{O}_{2}}{\longrightarrow} \mathrm{CH}_{3} \mathrm{C}(\mathrm{O}) \mathrm{OO}+\mathrm{H}_{2} \mathrm{O} \\
& \mathrm{CH}_{3} \mathrm{C}(\mathrm{O}) \mathrm{CH}_{3}+h v \stackrel{\mathrm{O}_{2}}{\longrightarrow} \mathrm{CH}_{3} \mathrm{C}(\mathrm{O}) \mathrm{OO}+\mathrm{CH}_{3} \\
& \mathrm{CH}_{3} \mathrm{COCHO}+\mathrm{hv} \stackrel{\mathrm{O}_{2}}{\longrightarrow} \mathrm{CH}_{3} \mathrm{C}(\mathrm{O}) \mathrm{OO}+\mathrm{HCO} .
\end{aligned}
$$

PAN can also be produced at night via reaction of acetaldehyde with the nitrate radical. Acetaldehyde, acetone and methylglyoxal are all directly emitted ("primary" sources) and produced in the atmosphere from oxidation of primary emitted NMVOCs ("secondary" sources). These different sources will be discussed below. There are also other minor sources of the PA radical, again to be discussed below.

Higher acyl peroxy nitrates $\left(\mathrm{RC}(\mathrm{O}) \mathrm{OONO}_{2}\right)$ are similarly formed from the oxidation of NMVOCs, but their yields are 
Table 1. Global contributions of primary NMVOCs to PAN formation ${ }^{\mathrm{a}}$.

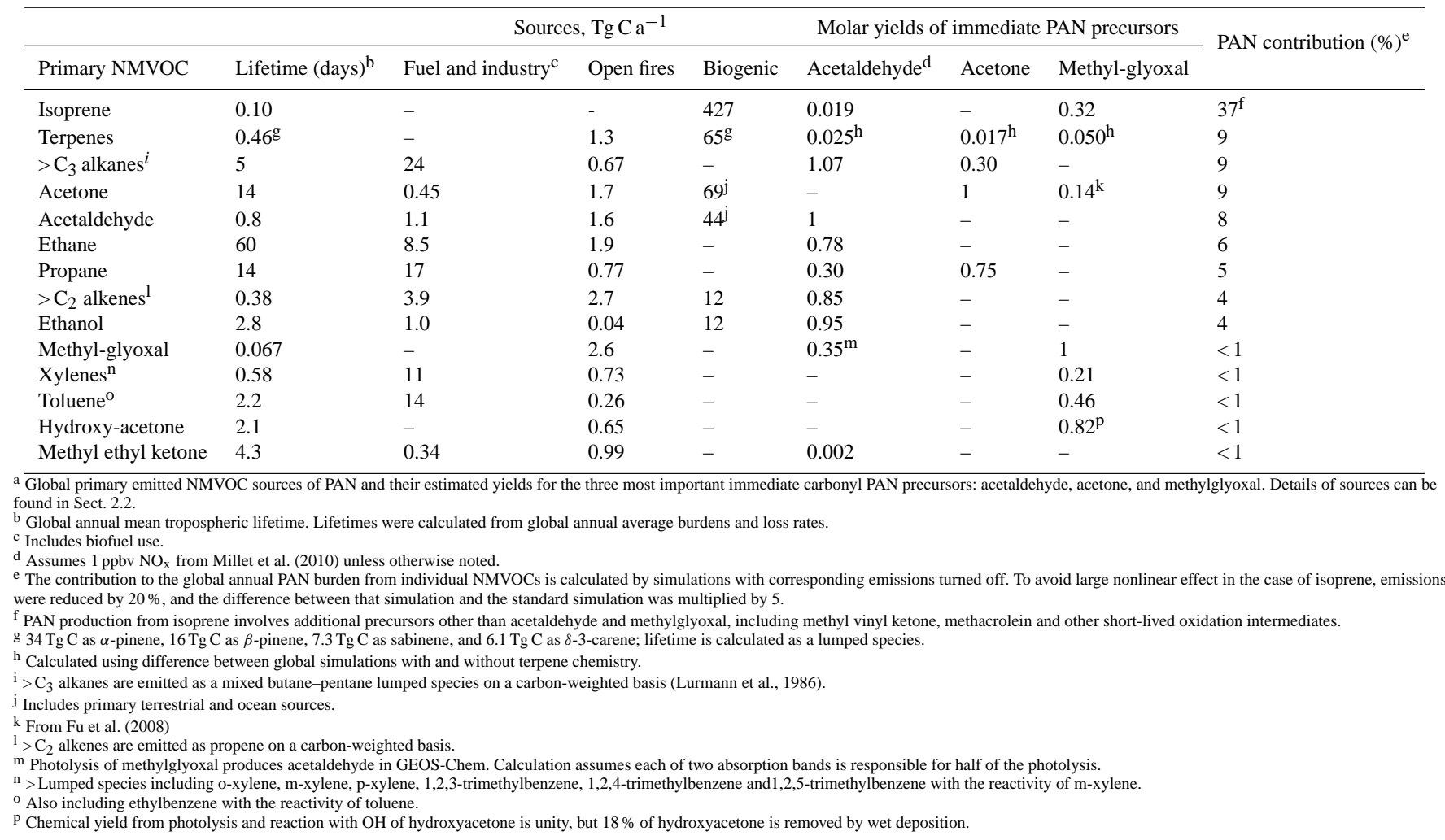

much lower than that for PAN. We focus on PAN because observations show that it typically accounts for $75-90 \%$ of total acyl peroxy nitrates (Roberts, 2007; Roberts et al., 1998, 2002; Wolfe et al., 2007) and there are an abundance of measurements of PAN. Closure on measurements of total reactive nitrogen oxides $\left(\mathrm{NO}_{\mathrm{y}}\right)$ confirms the dominant role of PAN as an organic nitrate reservoir for $\mathrm{NO}_{\mathrm{x}}$ (Roberts et al., 1995; Bertram et al., 2013).

The main sink of PAN is thermal decomposition (reaction 1), and the effective PAN lifetime depends on whether the released PA radical reacts with $\mathrm{NO}_{2}$ to return PAN, or with another species (mainly $\mathrm{NO}$ or $\mathrm{HO}_{2}$ ) leading to permanent loss. To describe this chemistry, GEOS-Chem uses the recommendation from Sander et al. (2011), which is taken from Bridier et al. (1991). The parameters recommended by Bridier et al. (1991) are consistent with later studies of PAN decomposition by Roberts and Bertman (1992), Orlando et al. (1992), and Grosjean et al. (1994). The rate coefficient for the reaction of the PA radical with NO is also from Tyndall et al. (2001).

Primary NMVOCs in the standard GEOS-Chem mechanism that contribute to PAN formation include ethane, propane, $>\mathrm{C}_{3}$ alkanes (lumped), $>\mathrm{C}_{2}$ alkenes (lumped), isoprene, acetaldehyde, methylglyoxal, acetone, and $>\mathrm{C}_{3}$ ketones (lumped). Our extended mechanism adds several additional primary NMVOCS, including ethanol, benzene, toluene and ethylbenzene (lumped), xylenes and trimethylbenzenes (lumped), and monoterpenes (lumped). The additions were partially motivated by the work of Ito et al. (2007), who extended the GEOS-Chem mechanism within the Integrated Massively Parallel Atmospheric Chemical Transport (IMPACT) CTM to include a broader suite of NMVOCs. One result of this exercise was a dramatic increase in PAN formation through methylglyoxal and hydroxyacetone. Liu et al. (2010) found aromatics to be a major source of PAN in urban China through the production of methylglyoxal. We calculate the associated yield of methylglyoxal using recommended values for the individual aromatic species (toluene, o-xylene, m-xylene, p-xylene, 1,2,3-trimethylbenzene, 1,2,4trimethylbenzene, and 1,3,5-trimethylbenzene) from Nishino et al. (2010) and the observed mean aromatic speciation for Chinese cities from Barletta et al. (2006).

We adopted the treatment of monoterpene oxidation from the RACM2 chemical mechanism (Goliff et al., 2013), lumping terpenes with one double bond (alpha-pinene, betapinene, sabinene and delta-3-carene) into one proxy. Unlike Ito et al. (2007), hydroxyacetone is not a product of terpene oxidation in the revised RACM2 mechanism used here. The gas phase oxidation of monoterpenes is highly unconstrained. The RACM2 mechanism is primarily based on Atkinson and Avery (2003). The yields of the immediate PAN precursors resulting from terpene degradation as 
described by RACM2 embedded in GEOS-Chem are given in Table 1. The mechanism produces methyl ethyl ketone and acetone, both of which can serve as PA radical precursors. The addition of this lumped terpene increases PAN in the model. The largest surface changes for PAN are for eastern Europe and western Russia, where there are high biogenic terpene emissions but there is little PAN data for comparison.

In addition to thermal decomposition, we include minor sinks for PAN from dry deposition and photolysis. The dry deposition velocity for PAN is simulated using a standard resistance-in-series approach (Wesely, 1989) as implemented in GEOS-Chem by Wang et al. (1998b). We assume that the PAN reactivity with surfaces is as strong as that of $\mathrm{O}_{3}$ (Shepson et al., 1992), but we explore the sensitivity to this choice. Photolysis and deposition account globally for $1.8 \%$ and $1.2 \%$ of the global PAN sink, respectively. Photolysis of PAN is important in the upper troposphere, where the lifetime against loss via photolysis is on the order of a month (Talukdar et al., 1995). We find that assuming PAN reactivity with surfaces is more similar to $\mathrm{O}_{3}$ rather than $\mathrm{NO}_{2}$ decreases surface PAN concentrations over Northern Hemisphere continents by $15-20 \%$ in spring. Reaction of PAN with both the $\mathrm{OH}$ radical and $\mathrm{Cl}$ atoms is slow, and these are both minor loss pathways, unnecessary to include in global models (Wallington et al., 1990; Talukdar et al., 1995). Uptake on ice particles in convective clouds (Marecal et al., 2010) and on organic aerosols (Roberts, 2005) are both thought to be negligible and are not included here. PAN is only sparingly soluble, but hydrolysis of the PA radical is thought to explain observed PAN loss in fog (Villalta et al., 1996; Roberts et al., 1996). We do not consider this to be a significant loss process for PAN on a global scale (Jacob, 2000).

\subsection{Emissions}

Production of PAN can be limited by the supply of either $\mathrm{NO}_{\mathrm{x}}$ or NMVOCs, as discussed below. Global fossil fuel emissions of $\mathrm{NO}_{\mathrm{x}}$ in GEOS-Chem are from the EDGAR inventory (Oliver and Berdowski, 2001) and are overwritten with regional inventories for Europe (EMEP) (Vestreng and Klein, 2002), Mexico (BRAVO) (Kuhns et al., 2003), eastern Asia (Zhang et al., 2009), Canada (NPRI, http://www.ec. gc.ca/inrp-npri/), and the United States (EPA/NEI2005, http://www.epa.gov/ttnchie1/net/2005inventory.html). All anthropogenic $\mathrm{NO}_{\mathrm{x}}$ emissions are scaled to 2008 based on energy statistics (van Donkelaar et al., 2008). Soil $\mathrm{NO}_{\mathrm{x}}$ emissions in GEOS-Chem are based on Yienger and Levy (1995) as implemented by Wang et al. (1998b). Lightning $\mathrm{NO}_{\mathrm{x}}$ emissions are described by Sauvage et al. (2007).

Table 1 lists the global emissions of all NMVOCs that contribute to PAN formation. We use the RETRO (REanalysis of the TROpospheric chemical composition) emission inventory (van het Bolscher et al., 2008) as the global default for anthropogenic NMVOC emissions aside from ethane and propane. Ethane and propane emissions in RETRO were far too low compared to the GEOS-Chem inventories from Xiao et al. (2008), which are unbiased relative to observations. Emissions of both species appeared to be missing from the major natural gas production region in Russia. We used the ethane and propane emission inventories which were developed as in Xiao et al. (2008). The RETRO emission inventory is for 2000, and we scaled it to 2008 following van Donkelaar et al. (2008). RETRO includes anthropogenic emissions for benzene, xylene and toluene. Based on the observed CO-tobenzene ratio for TRACE-P, we increased benzene emissions over China by $25 \%$. We then scaled xylene and toluene emissions to benzene based on measurements from 43 Chinese cities from Barletta et al. (2006). Thus RETRO emissions of toluene were increased by a factor of 4 over China to create our lumped toluene, and RETRO emissions of xylene were increased by a factor of 8 over China to create our lumped xylene species. Observations show large abundances of reactive aromatics over southern and eastern China (Ran et al., 2009; Wang et al., 2002, 2013; Zhang et al., 2007a).

Terrestrial biogenic emissions of acetone, acetaldehyde, isoprene, ethanol, terpenes, and $>\mathrm{C}_{2}$ alkenes from metabolism and decay are calculated locally using the Model of Emissions of Gases and Aerosols from Nature (MEGAN v2.0) (Guenther et al., 2006). Specific other sources and sinks for acetone and acetaldehyde are described in Fischer et al. (2012) and Millet et al. (2010), respectively. The atmospheric budget of ethanol is also as described by Millet et al. (2010).

New estimates indicate that fires emit significantly more NMVOCs than previously thought (Wiedinmyer et al., 2011), and there is a large contribution from oxygenated species, many of which are unidentified (Warneke et al., 2011). Observations show rapid conversion of $\mathrm{NO}_{\mathrm{x}}$ to PAN in fire plumes, seemingly due to the oxidation of very shortlived NMVOCs (Jacob et al., 1992). We use 2008 Global Fire Emissions Database (GFED3) monthly biomass burning emissions for $\mathrm{NO}_{\mathrm{x}}$ and NMVOCs (van der Werf et al., 2010) with updated emission factors for NMVOCs and $\mathrm{NO}_{\mathrm{x}}$ from extratropical forests, savannas and agricultural fires from Akagi et al. (2011). The updated $\mathrm{NO}_{\mathrm{x}}$ emission factor for extratropical fires is approximately a factor of three lower, and the emission factors for the NMVOCs are generally higher. Following Alvarado et al. (2010) we partition $40 \%$ and $20 \%$ $\mathrm{NO}_{\mathrm{x}}$ emissions from fires directly to $\mathrm{PAN}$ and $\mathrm{HNO}_{3}$, respectively. The Alvarado et al. (2010) partitioning is based on observations of fresh boreal fire plumes, but we apply it here to all fire types. Our additional NMVOC budgets include the addition of biomass burning emissions as given in Table 1 .

The standard version of GEOS-Chem releases all fire emissions in the boundary layer; however, previous studies have pointed out that a significant fraction of biomass burning emissions can be injected to the free troposphere because of buoyancy (Turquety et al., 2007; Val Martin et al., 2010). This is especially important for PAN because 
lower temperatures above the boundary layer enhance its stability. Val Martin et al. (2010) showed that a substantial fraction of plumes from North American fires are injected into the free troposphere. Smoke plumes over the boreal region reached the highest altitudes. Analysis of smoke clouds, which are a later stage of plume evolution, indicated that $\sim 35 \%$ were above the boundary layer. Here we distribute $35 \%$ of biomass burning emissions by mass in the 10 sigma layers $(4 \mathrm{~km})$ above the boundary layer, and this improves our comparison with PAN observations at high latitudes. The PAN simulation is sensitive to this choice.

Kaiser et al. (2012) and Yue et al. (personal communication) find that GFED3 underestimates fire emissions by not accounting for small fires, particularly at boreal latitudes. Following their work, we increased wild fire emissions by $60 \%$ in northern Asia $\left(30-75^{\circ} \mathrm{N}, 60-190^{\circ} \mathrm{E}\right), 25 \%$ in Canada and $50 \%$ in Alaska. Increasing fire emissions over Russian and North American boreal regions improves the PAN simulation over the Arctic, particularly above the surface

\subsection{Model configuration}

In our work GEOS-Chem is driven by NASA GEOS-5 assimilated meteorological data with $0.5^{\circ} \times 0.67^{\circ}$ horizontal resolution, 47 levels in the vertical, and $3-6 \mathrm{~h}$ temporal resolution. We degrade the horizontal resolution to $2^{\circ} \times 2.5^{\circ}$ for input into our GEOS-Chem simulation. We use a 1 -year simulation for 2008 , preceded by a 1 -year spin-up to remove the effect of initial conditions. We also present a number of sensitivity simulations conducted at $4^{\circ} \times 5^{\circ}$ horizontal resolution, which yield results very similar to the $2^{\circ} \times 2.5^{\circ}$ resolution. The largest differences in the two resolutions occur over regions of biomass burning. Over these locations, the finer horizontal resolution produces 10 $20 \%$ more PAN. The likely explanation is that vertical transport is faster at higher resolution because eddies are not averaged out. This was first shown by Wang et al. (2004) using a nested simulation for $\mathrm{CO}$ over Asia.

Throughout the paper we present results using 2008 GEOS-5 assimilated meteorology. However we have compared results using both GEOS-4 and GEOS-5 for 2006, the last year of overlap for these two meteorological data sets. The lifetime of PAN doubles for every $4 \mathrm{~K}$ decrease in temperature. PAN is also sensitive to biogenic emissions, lightning $\mathrm{NO}_{\mathrm{x}}$ emissions and vertical transport (Labrador et al., 2005), parameters that also depend on the underlying meteorological field. We found that differences in the monthly mean PAN produced using different assimilated meteorological grids are substantial in some locations (> $100 \mathrm{pptv})$. Higher upper-tropospheric PAN mixing ratios over the tropical Pacific in GEOS-5 appear to be driven by slower convective overturning in GEOS-5 than GEOS-4. GEOS-4 agrees better with data from PEM-Tropics B (Maloney et al., 2001). The PEM-Tropics B data set suggests very low $(<50 \mathrm{pptv})$
PAN mixing ratios in the Pacific tropical UT. Differences between the simulated and observed $\mathrm{O}_{3}$ profiles for the PEM-Tropics B regions are consistent with the view that differences in vertical motion are driving the PAN differences. There are limited opportunities to chemically constrain convective overturning in data assimilation models. However, existing analyses suggest substantial differences between overturning rates derived from in situ measurements and those in GEOS-4 (Bertram et al., 2007). Mitoviski et al. (2012) assessed the impact of convection on $\mathrm{O}_{3}$ in GEOS-Chem and found tropical upper-tropospheric $\mathrm{O}_{3}$ biases driven by the parameterized vertical transport in both GEOS-4 and GEOS-5.

\section{Global PAN distribution}

We used a large database of recent PAN observations from surface sites and airborne campaigns to evaluate the model, and these are presented in Table 2. For comparison to the model, we averaged the aircraft observations over the coherent regions in Fig. 1. The measurements either relied on gas chromatography with electron capture detector (GC-ECD) (Flocke et al., 2005) or thermal decomposition chemical ionization mass spectrometry (TD-CIMS) (Zheng et al., 2011).

Figures 2 and 3 compare the observed global distribution of PAN to that simulated by GEOS-Chem. Mean observations from the studies compiled in Table 2 are shown as filled circles. Model fields are background contours. Full vertical profiles (median and mean) for the aircraft campaigns and seasonal cycles for several European mountaintop data sets are in the supplementary materials. We compare model output from 2008 to observations collected over many years. Interannual variability in the model is smaller than other sources of error. There are relatively few in situ observations that can be used to assess interannual variability in PAN (Bottenheim et al., 1994). Observations at Mount Bachelor (Oregon, USA) indicate interannual variability of $20 \%$ during the spring maximum (Fischer et al., 2011). Recent trends in PAN in many regions of the atmosphere are also hard to assess given a paucity of consistent data (Parrish et al., 2004). As shown later PAN is highly sensitive to $\mathrm{NO}_{\mathrm{x}}$ and NMVOC emissions, both of which have changed considerably in some regions (Pollack et al., 2013).

Figure 2 indicates that spring and summer Northern Hemisphere average PAN abundances below $6 \mathrm{~km}$ are comparable over polluted continental regions. The Northern Hemisphere springtime maximum, previously attributed to photochemical production at a time when PAN has a long thermal lifetime (Penkett and Brice, 1986; Brice et al., 1988), is primarily a feature of remote air. Long-term PAN measurements from the Hohenpeissenberg and Schauinsland European mountaintop observatories, both primarily within the atmospheric boundary layer, show either spring or summer maxima depending on the year (Supplement Fig. 2). Pandey 
Table 2. Global PAN measurements used for model evaluation listed in order of map regions labeled in Fig. 2.

\begin{tabular}{|c|c|c|c|c|}
\hline \multicolumn{5}{|c|}{ Aircraft missions } \\
\hline Experiment & Time frame & Location & Fig. 1 map regions & Reference \\
\hline TRACE-P & Mar-Apr 2001 & W Pacific & $1,2,5,6$ & Talbot et al. (2003) \\
\hline PEM-West B & Feb-Mar 1994 & W Pacific & 3 & Singh et al. (1998) \\
\hline PEM-West A & Sep-Oct 1991 & W Pacific & $4,7,8$ & Singh et al. (1996b) \\
\hline PEM-Tropics B & Mar-Apr 1999 & Tropical Pacific & $9-13$ & Maloney et al. (2001) \\
\hline PEM-Tropics A & Aug-Oct 1996 & S Pacific & 14-17 & Talbot et al. (2000) \\
\hline INTEX-B & Mar-May 2006 & E Pacific & $18-20$ & Singh et al. (2009) \\
\hline PHOBEA & Mar-Apr 1999 & E Pacific & 21 & Kotchenruther et al. (2001) \\
\hline ITCT-2K2 & Apr-May 2002 & E Pacific & 22 & Roberts et al. (2004) \\
\hline MILAGRO & Mar-May 2006 & Mexico & 23 & Singh et al. (2009) \\
\hline CITE-2 & Aug-Sep 1986 & W US & $24-25$ & Singh et al. (1990a) \\
\hline INTEX-A & Jul-Aug 2004 & Eastern N America & $26-28$ & Singh et al. (2006) \\
\hline SONEX & Oct-Nov 1997 & N Atlantic & 29,42 & Talbot et al. (1999) \\
\hline ABLE-2B & Apr-May 1987 & Amazon & 30 & Singh et al. (1990b) \\
\hline TRACE-A & Sep-Oct 1992 & S Atlantic & $31-32,43-45$ & Singh et al. (1996a) \\
\hline ABLE-3A & Jul-Aug 1988 & Alaska & 33 & Singh et al. (1992) \\
\hline ABLE-3B & Jul-Aug 1990 & E Canada & $34-35$ & Singh et al. (1994) \\
\hline ARCTAS & Apr-Jul 2008 & N American Arctic & $36-38$ & Alvarado et al. (2010) \\
\hline ARCPAC & Mar-Apr 2008 & Alaska & 39 & Slusher et al. (2004) \\
\hline POLARCAT & July 2008 & Greenland & 40 & Roiger et al. (2011) \\
\hline TOPSE & Feb-Mar 2000 & N American Arctic & 41 & Atlas et al. (2003) \\
\hline AMMA & Aug 2006 & West Africa & 46 & Stewart et al. (2008) \\
\hline \multicolumn{5}{|c|}{ Surface measurements } \\
\hline Site name & Time frame & Location & Elevation & Reference \\
\hline Mount Bachelor & Mar-May 2008-2010 & $44^{\circ} \mathrm{N}, 122^{\circ} \mathrm{W}$ & $2.7 \mathrm{~km}$ & Fischer et al. (2010) \\
\hline Jungfraujoch & 1997-1998, 2005-2006, 2008 & $47^{\circ} \mathrm{N}, 9^{\circ} \mathrm{E}$ & $3.6 \mathrm{~km}$ & $\begin{array}{l}\text { Balzani Loov et al. (2008); Whalley et al. (2004); } \\
\text { Zellweger et al. (2000); Pandey Deolal et al. (2013) }\end{array}$ \\
\hline Hohenpeissenberg & 2003-2008 & $48^{\circ} \mathrm{N}, 1^{\circ} \mathrm{E}$ & $985 \mathrm{~m}$ & http://ds.data.jma.go.jp/gmd/wdcgg/ \\
\hline Schauinsland & $1995-2010$ & $48^{\circ} \mathrm{N}, 8^{\circ} \mathrm{E}$ & $1.2 \mathrm{~km}$ & http://ds.data.jma.go.jp/gmd/wdcgg/ \\
\hline Zugspitze & 2004-2008 & $47^{\circ} \mathrm{N}, 11^{\circ} \mathrm{E}$ & $2.7 \mathrm{~km}$ & http://ds.data.jma.go.jp/gmd/wdcgg/ \\
\hline Waliguan & Jul-Aug 2006 & $36^{\circ} \mathrm{N}, 101^{\circ} \mathrm{E}$ & $3.8 \mathrm{~km}$ & Xue et al. (2011) \\
\hline Bush Estate & 1994-1998 & $56^{\circ} \mathrm{N}, 3^{\circ} \mathrm{W}$ & $200 \mathrm{~m}$ & McFadyen and Cape (2005) \\
\hline Rishiri & 1999 & $45^{\circ} \mathrm{N}, 141^{\circ} \mathrm{E}$ & $35 \mathrm{~m}$ & Tanimoto et al. (2002) \\
\hline Poker Flat & Mar-May 1993, 1995 & $65^{\circ} \mathrm{N}, 148^{\circ} \mathrm{W}$ & $470 \mathrm{~m}$ & Beine et al. (1996) \\
\hline Alert & Jan-Apr 1992, 1998, 2000 & $82^{\circ} \mathrm{N}, 62^{\circ} \mathrm{W}$ & $200 \mathrm{~m}$ & Dassau et al. (2004); Worthy et al. (1994) \\
\hline Zeppelin & $1994-1998$ & $78^{\circ} \mathrm{N}, 16^{\circ} \mathrm{W}$ & $474 \mathrm{~m}$ & Beine et al. (1997); Beine and Krognes (2000) \\
\hline Polarstern Cruise & May-Jun 1998 & $52^{\circ} \mathrm{N}-17^{\circ} \mathrm{S}, 7^{\circ} \mathrm{E}-19^{\circ} \mathrm{W}$ & Sea level & Jacobi et al. (1999) \\
\hline Thompson Farm & $2005-2007$ & $43^{\circ} \mathrm{N}, 71^{\circ} \mathrm{W}$ & $25 \mathrm{~m}$ & Robert Talbot, Ryan Chartier, unpublished data \\
\hline Summit, Greenland & Jun-Jul 1998, Jan 1999 & $47^{\circ} \mathrm{N}, 9^{\circ} \mathrm{E}$ & $3.2 \mathrm{~km}$ & Ford et al. (2002) \\
\hline Pico Mountain & Jul-Sep 2008, Mar-Jul 2009 & $38^{\circ} \mathrm{N}, 28^{\circ} \mathrm{W}$ & $2.2 \mathrm{~km}$ & Katja Dzepina, Jim Roberts, unpublished data \\
\hline
\end{tabular}

Deolal et al. (2013) found that the PAN spring maximum at Jungfraujoch is mainly attributable to air masses advected from the polluted European boundary layer, and PAN formation in the free troposphere does not play a dominant role. Both the model and surface observations indicate that the springtime maximum is pronounced over the Arctic, and this has previously been attributed to transport of northern midlatitudes pollution (Moxim et al., 1996). We find that springtime fires in Russia and China also contribute to this feature, and this is discussed later in the context of our sensitivity simulations.

Successful simulation of PAN in Asian outflow is contingent on the inclusion of emissions of aromatic species. These account for $30 \%$ of the PAN in that region in the model. Even with the addition of aromatics, the model is biased low for this region. This could suggest missing NMVOC emissions in China, as suggested by Fu et al. (2007), or unrealistically low PA radical yields from aromatics in the chemical scheme. The model largely reproduces the average vertical profiles observed during TRACE-P (see vertical profiles in Supplement Fig. 1), but these were collected in 2001 and the model output is for 2008. Chinese $\mathrm{NO}_{\mathrm{x}}$ and NMVOCs emissions have increased by more than 55 and $29 \%$ over this period, respectively (Zhang et al., 2007b, 2009).

PAN is also sensitive to the parameterization of the uptake of the hydroperoxyl radical $\left(\mathrm{HO}_{2}\right)$ by aerosols. Recent work (Mao et al., 2013a) suggests that the reactive uptake of $\mathrm{HO}_{2}$ is a much more efficient sink of $\mathrm{HO}_{\mathrm{x}}$ than previously thought or than is implemented here (Thornton et al., 2008). We tested the impact of more efficient uptake of $\mathrm{HO}_{2}$ by aerosols on PAN by setting the reactive uptake coefficient of $\mathrm{HO}_{2}$ to 1 and eliminating conversion of $\mathrm{HO}_{2}$ to $\mathrm{H}_{2} \mathrm{O}_{2}$ on 


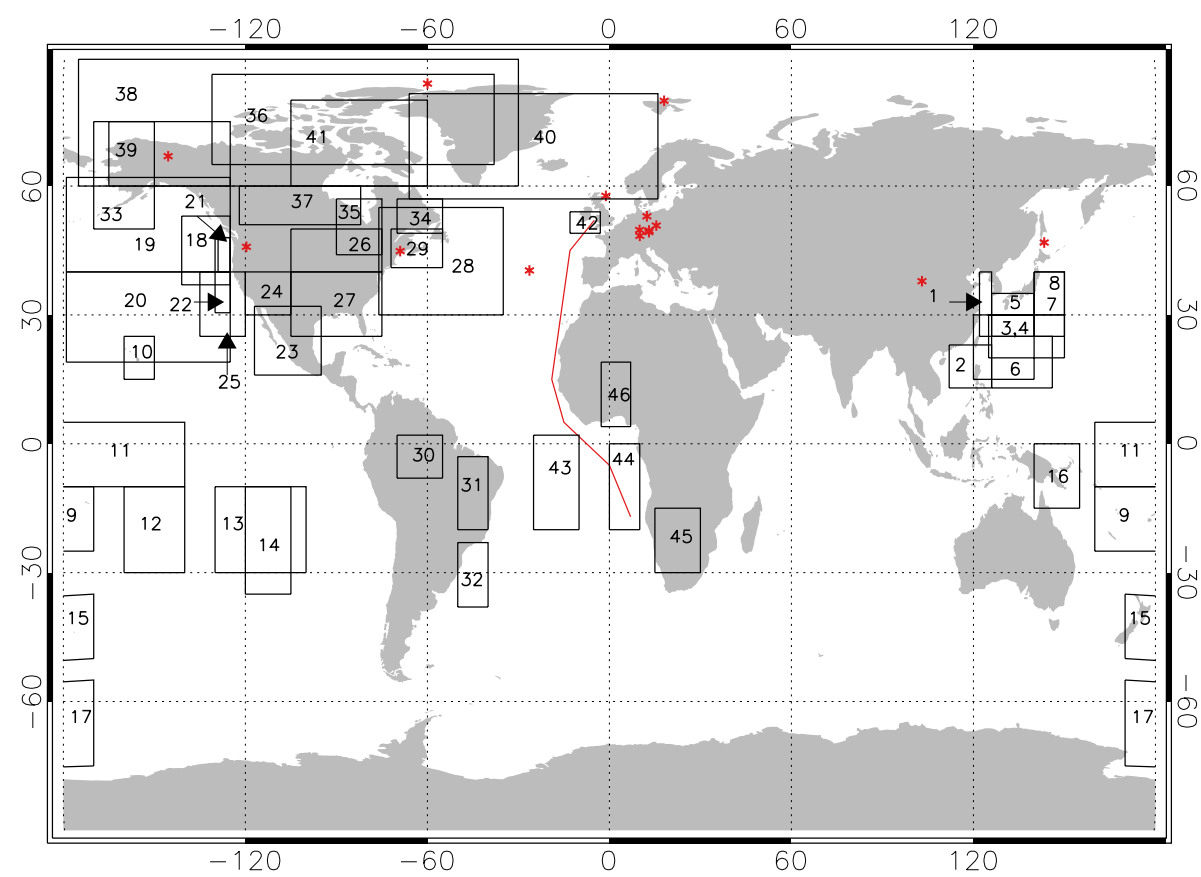

Fig. 1. Locations of PAN observations used in our analysis (Table 2): surface sites (red asterisk); aircraft missions (black boxes) with region numbers indicated; and one cruise (red line).

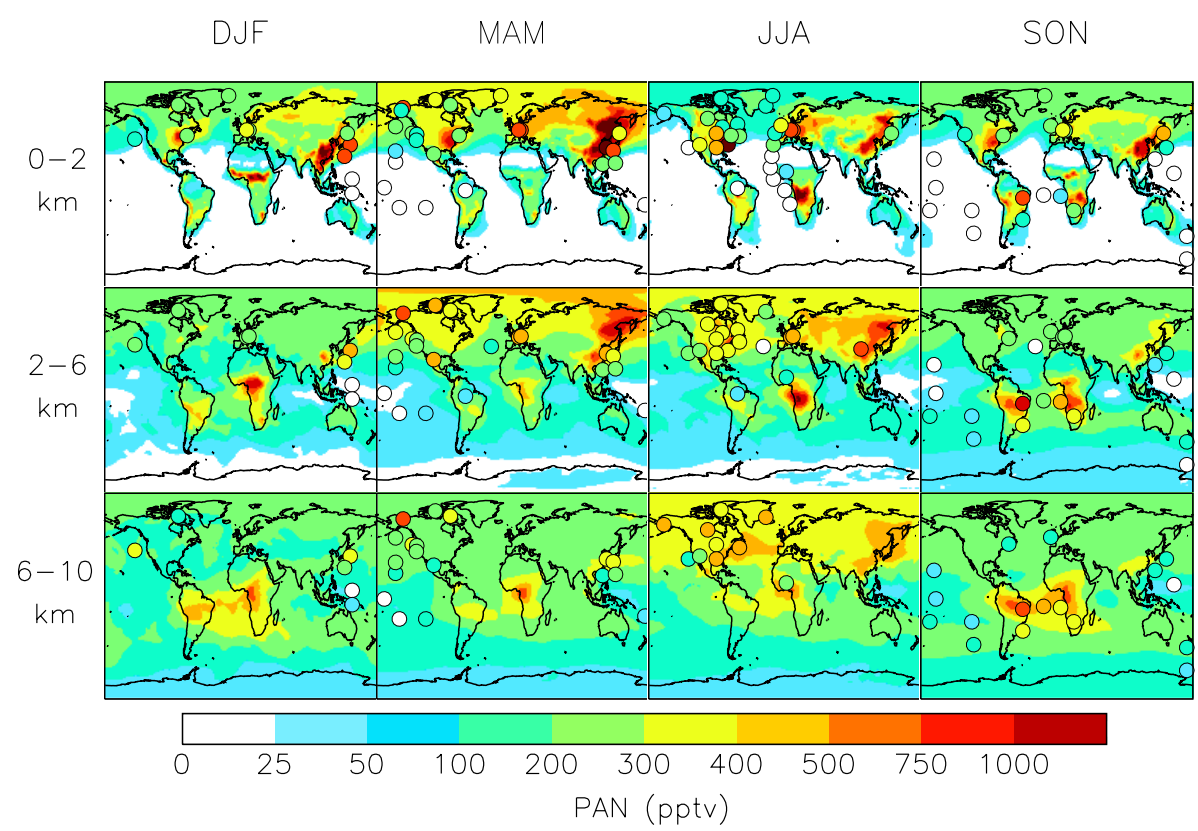

Fig. 2. Global mean distribution of PAN for different seasons and altitude ranges. Model results for 2008 (background solid contours) are compared to observations from Table 2 for all years (filled circles). Aircraft observations are averaged vertically and horizontally over the coherent regions of Fig. 2.

aerosols. We found that the faster uptake of $\mathrm{HO}_{2}$ drastically reduced (50\%) springtime PAN over eastern Asia. The faster uptake produces springtime PAN outflow in the model that is inconsistent with observations in that region, and would imply a large missing source of PAN.
Though the differences are smaller, PAN observations from European mountaintop sites also suggest missing PAN sources there. These PAN observations have not been used to justify emissions changes as observations from both Zugspitze $(2658 \mathrm{~m})$ and Jungfraujoch $(3580 \mathrm{~m})$ reflect 
terrain-induced injections of PAN-rich boundary layer air (Zanis et al., 2003, 2007; Zellweger et al., 2000; Carpenter et al., 2000; Pandey Deolal et al., 2013), and this transport scale is not captured in the model. However, Figure 3 indicates that the observations are also higher than the model output below the altitude of the measurements.

In Northern Hemisphere summer, both the model and observations show a strong contrast between high concentrations over source continents and adjacent oceans (Fig. 3), reflecting the short lifetime of PAN against thermal decomposition. PAN concentrations in the model are generally higher aloft, consistent with INTEX-A aircraft observations over the eastern US $\left(90^{\circ} \mathrm{W}-45^{\circ} \mathrm{W}\right.$, panel 3, Fig. 3) and measurements from the Azores (Val Martin et al., 2008), reflecting the longer PAN lifetime. The INTEX-A observations indicate that PAN mixing ratios begin to decrease with altitude above $8 \mathrm{~km}$ over the northeastern US and the western Atlantic, but not over the southeastern US where lightning and convection support PAN production aloft (Hudman et al., 2007).

The lowest three panels of Fig. 3 show that outside of winter months there is a reservoir of 200-400 pptv PAN between 5 and $8 \mathrm{~km}$ over northern midlatitudes. A similar PAN reservoir aloft has also been observed over the Arctic during aircraft campaigns in spring and summer (Singh et al., 1994). PAN can be $80-90 \%$ of total $\mathrm{NO}_{\mathrm{y}}$ in the cold Arctic atmosphere (Atlas et al., 2003; Jaffe et al., 1997; Bottenheim et al., 1986). Liang et al. (2011) note that the 2008 ARCTAS PAN observations are not notably different from either the 1988 ABLE or 2000 TOPSE observations, despite dramatic changes to $\mathrm{NO}_{\mathrm{x}}$ emissions in the major anthropogenic source regions. In the upper troposphere, Northern Hemisphere PAN mixing ratios peak in summer, with contributions from anthropogenic sources, biomass burning and lightning. This summertime upper-tropospheric maximum is consistent with MIPAS retrievals for $300-150 \mathrm{hPa}$ which indicate the highest Northern Hemisphere PAN concentrations in August and the lowest PAN from October to January (Moore and Remedios, 2010).

The Polarstern Cruise data from Germany to South Africa in summer reveal a sharp meridional gradient, with mixing ratios dropping below the detection limit ( $25 \mathrm{pptv})$ outside northern midlatitudes (Fig. 2) (Jacobi et al., 1999). The meridional gradient is much less defined in the free troposphere, reflecting biogenic and fire contributions in the southern tropics with efficient convective lofting (Fig. 2).

We see from the SON seasonal mean plots in Fig. 2 that the Southern Hemisphere features a spring PAN maximum in the upper troposphere, similar to the remote northern extratropics. Moore and Remedios (2010) observed a spring PAN maximum in the upper troposphere at $0-35^{\circ} \mathrm{S}$ from MIPAS retrievals and attributed it to seasonal biomass burning over central Africa. Moxim et al. (1999) also simulated the Southern Hemisphere springtime free-tropospheric PAN maximum, but suggested that it is driven by convective transport rapidly mixing PAN upward from continental surface
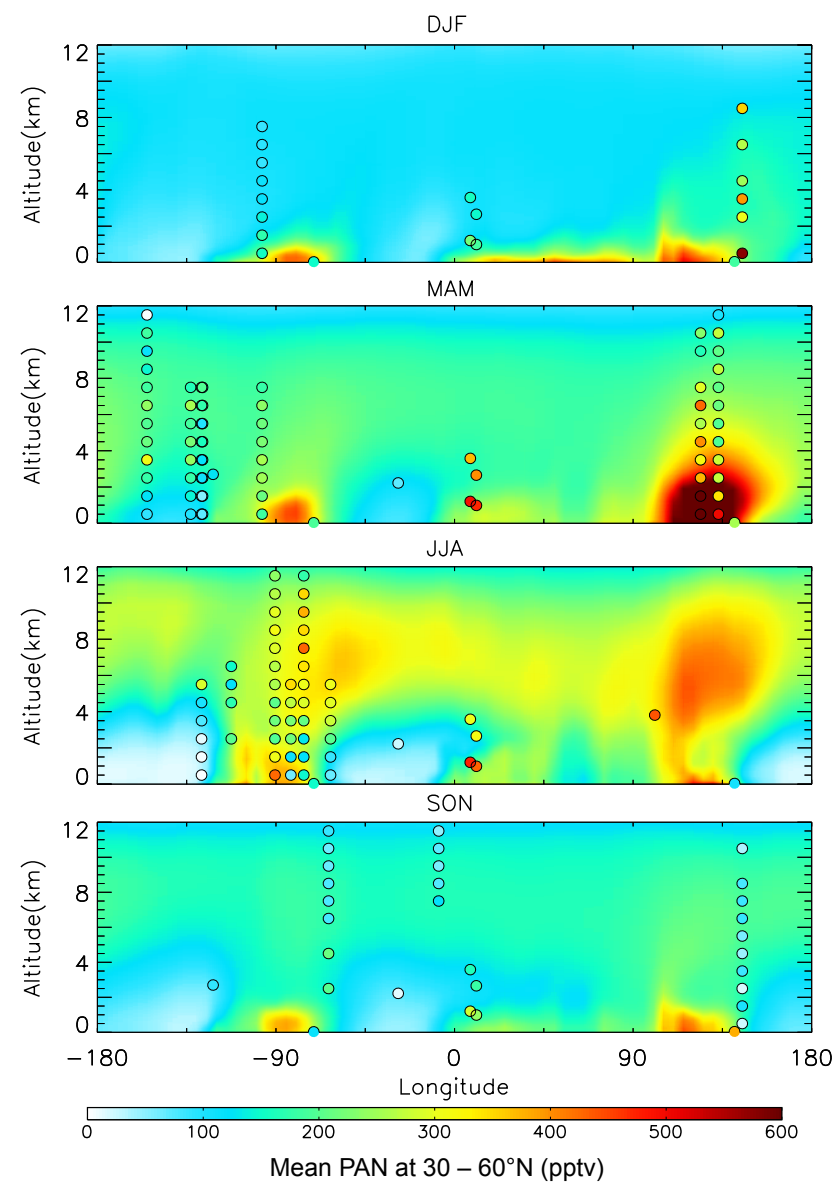

Fig. 3. Longitudinal cross-section of seasonal mean PAN concentrations at northern midlatitudes $\left(30-60^{\circ} \mathrm{N}\right)$ as a function of altitude. Model results for 2008 (background solid contours) are compared to observations from many years in Table 2 (filled circles). Circles are placed at the mean longitude of the coherent regions (Fig. 2) that fall between $\left(30-60^{\circ} \mathrm{N}\right)$.

production regions. As discussed below, our model suggests that much of the PAN in the austral free troposphere is due to continental convective injection of biogenic NMVOCs together with the lightning $\mathrm{NO}_{\mathrm{x}}$ source.

\section{Contributions of different NMVOCs to PAN formation}

PAN depends on NMVOCs and $\mathrm{NO}_{\mathrm{x}}$ in nonlinear ways. To diagnose this dependence and identify the most critical precursor, we conducted two sensitivity studies where $\mathrm{NO}_{\mathrm{x}}$ and NMVOC emissions were separately reduced by $20 \%$ across all sectors. The results are presented in Fig. 4. We see that PAN concentration depends in general more strongly on NMVOC than $\mathrm{NO}_{\mathrm{x}}$ emissions. Exceptions are fire-dominated regions at northern high latitudes, reflecting the very low $\mathrm{NO}_{\mathrm{x}} / \mathrm{NMVOCs}$ emission ratio from fires. This result is also 


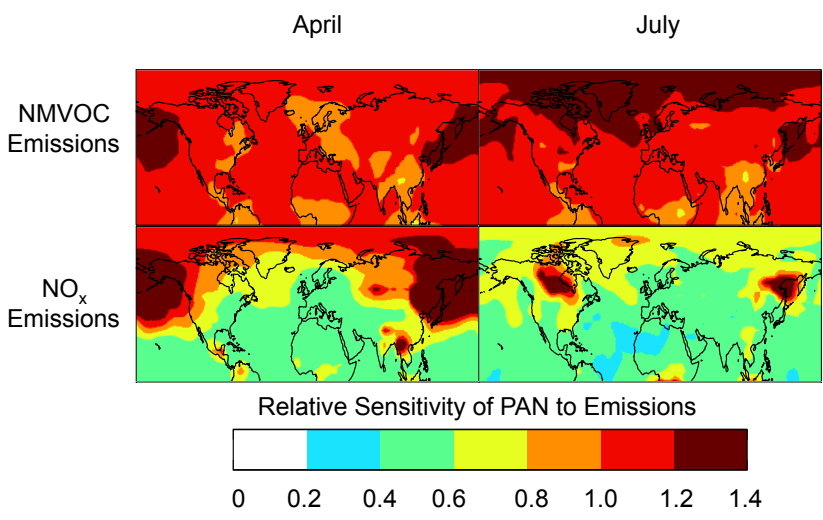

Fig. 4. Relative sensitivity of total column PAN concentrations to emissions of $\mathrm{NO}_{\mathrm{x}}$ and NMVOCs in April and July. The sensitivity is diagnosed as $\triangle \mathrm{PAN} / \Delta E$, where $\triangle \mathrm{PAN}$ is the change in monthly mean PAN column concentrations resulting from a $20 \%$ decrease $\Delta E$ in global emissions of either NMVOCs (top) or $\mathrm{NO}_{\mathrm{x}}$ (bottom), including all sources and sustained year-round. Zero indicates no sensitivity, while one indicates $1: 1$ sensitivity.

partially an artifact of partitioning $40 \%$ of GFED fire $\mathrm{NO}_{\mathrm{x}}$ emissions directly to PAN. A remarkable result is that PAN responds supra-linearly to NMVOC emissions in many locations, with the strongest effect over the North Pacific in spring and over the Arctic in summer. In both of these regions PAN is a principal source of $\mathrm{NO}_{\mathrm{x}}$ (Singh et al., 1992; Zhang et al., 2008), so that reducing PAN causes decreases in $\mathrm{O}_{3}$, in turn decreasing the $\left[\mathrm{NO}_{2}\right] /[\mathrm{NO}]$ ratio and thus reducing the effective lifetime of PAN. This chemical feedback amplifies the sensitivity of PAN to NMVOC emission changes. Another chemical feedback in source regions is that reducing NMVOC emissions increases the concentration of $\mathrm{OH}$ and hence the conversion of $\mathrm{NO}_{\mathrm{x}}$ to nitric acid.

In order to understand the contributions of different NMVOC precursors to PAN formation, we conducted 14 sensitivity simulations where the emissions of each precursor in the leftmost column of Table 1 were turned off individually. The change in the total burden of PAN was compared to a standard simulation with all emissions switched on. In the case of isoprene where the effect is large, we reduced emissions by $20 \%$ (and multiplied the change by 5 ) in order to minimize nonlinear effects. Figure 5 presents a schematic of the relative contributions of individual NMVOCs to global PAN formation through the major carbonyl species (acetaldehyde, acetone, methylglyoxal) serving as precursors of PAN (Reactions (R2)-(R4)). The absolute contributions are in Table 1. Anthropogenic, biogenic and biomass burning emissions make significant contributions to all three of the most important immediate PAN precursors (acetaldehyde, acetone, and methylglyoxal). We track PA radical formation via four different chemical pathways, from acetaldehyde, acetone, methylglyoxal and all other intermediate species. The bottom pie chart in Fig. 5 summarizes the relative importance of these four pathways for global annual total PA radical production.

Figure 6 summarizes the geographical distribution of annual total PA radical production for the lower, mid- and upper troposphere. PA production is strongest in NMVOC source regions, propagating to the free troposphere in the tropics through deep convection. The patterns in Fig. 6 reflect the dominant sources and lifetime for each PA radical precursor: mean lifetimes $1-2 \mathrm{~h}$ for methylglyoxal, 0.8 days for acetaldehyde and 14 days for acetone. The bottom row of Fig. 6 shows total PA radical production from other pathways, mainly via isoprene and monoterpene oxidation intermediates, including methyl vinyl ketone and methacrolein. These latter species contribute to PA radical formation predominantly via photolysis. We traced PA radical formation via these species together with all other intermediates.

Figures 5 and 6 reveal that acetaldehyde is the most important PA radical precursor globally, responsible for $\sim 40 \%$ of total PA radical production at all altitudes. Photochemical production is the dominant source of acetaldehyde, with large contributions from both biogenic and anthropogenic primary emissions (Fig. 5). There is also PA production from acetaldehyde in the marine boundary layer, partially reflecting the ocean acetaldehyde source (Millet et al., 2010). The alkanes, $>\mathrm{C}_{2}$ alkenes and ethanol all have high molar yields for acetaldehyde (Table 1). Though most originate over continents, the lifetimes of the primary precursors of acetaldehyde range from hours (isoprene) to months (ethane). Thus there is significant production of the PA radical from acetaldehyde at all altitudes over both continental regions and the downwind oceans (Millet et al., 2010).

Based on global simulations with and without acetone, Singh et al. (1995) estimated that up to $50 \%$ of observed PAN in the mid-upper troposphere could be formed from acetone. However, they assumed a photolysis rate for acetone now known to be too high. Using a similar approach and the acetone budget from Fischer et al. (2012), we find that the contribution of acetone to PAN is $25 \%$ in the upper troposphere over the Northern Hemisphere during summer and less under other conditions. Acetone is the most important PA precursor only in the most remote regions of the upper troposphere.

Isoprene and monoterpenes are also important precursors for PAN formation through methylglyoxal and other intermediates. Due to relatively short lifetimes, their role is largest in continental boundary layers (Fig. 6). von Kuhlmann et al. (2004) showed that PAN formation in models is highly sensitive to the treatment of isoprene chemistry, and there have been a number of more recent advances regarding the oxidation chemistry of isoprene (Lelieveld et al., 2008; Paulot et al., 2009b; Peeters et al., 2009; Mao et al., 2012). There are also ongoing efforts to determine appropriate yields for methylglyoxal and other important intermediates under the high- $\mathrm{NO}_{\mathrm{x}}$ conditions most relevant for PAN formation (Galloway et al., 2011). Implementation of the Paulot et 


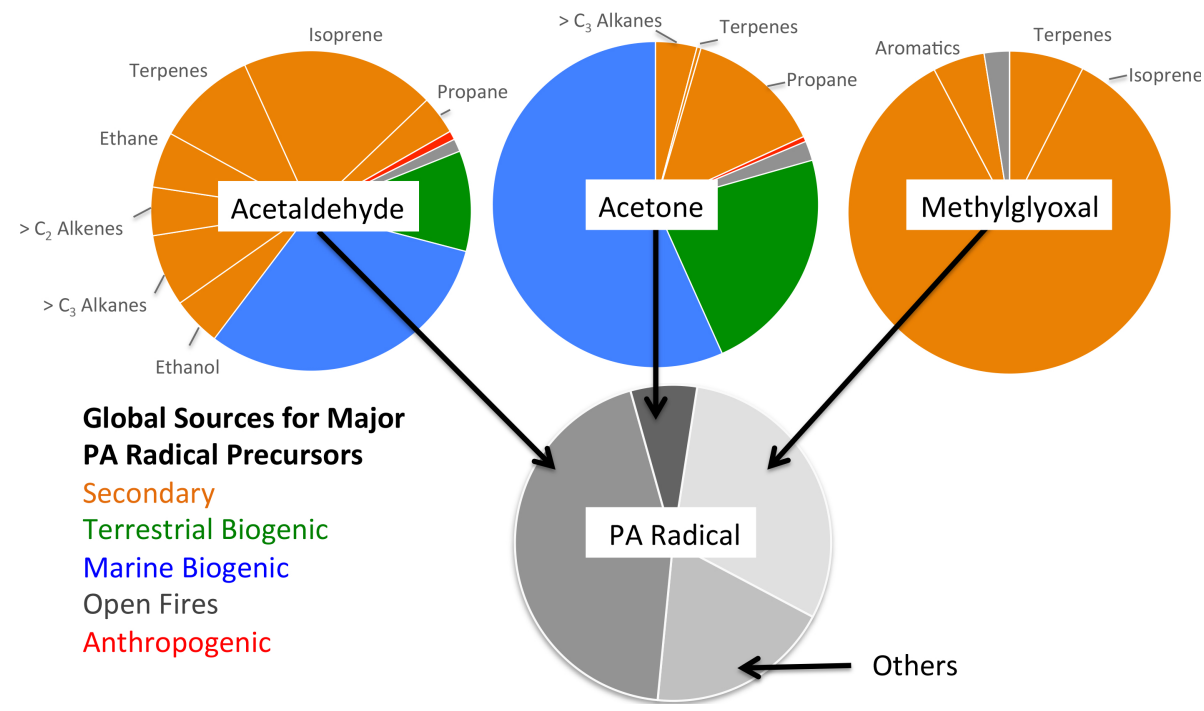

Fig. 5. Global contributions of individual NMVOCs to PAN formation, expressed as the relative contributions to the major carbonyl species producing the peroxyacetyl radical (PA), and from there the relative contributions of the carbonyl species to global PA production. Values are from Table 1. The geographical and vertical distribution of total PA radical production is given in Fig. 6.
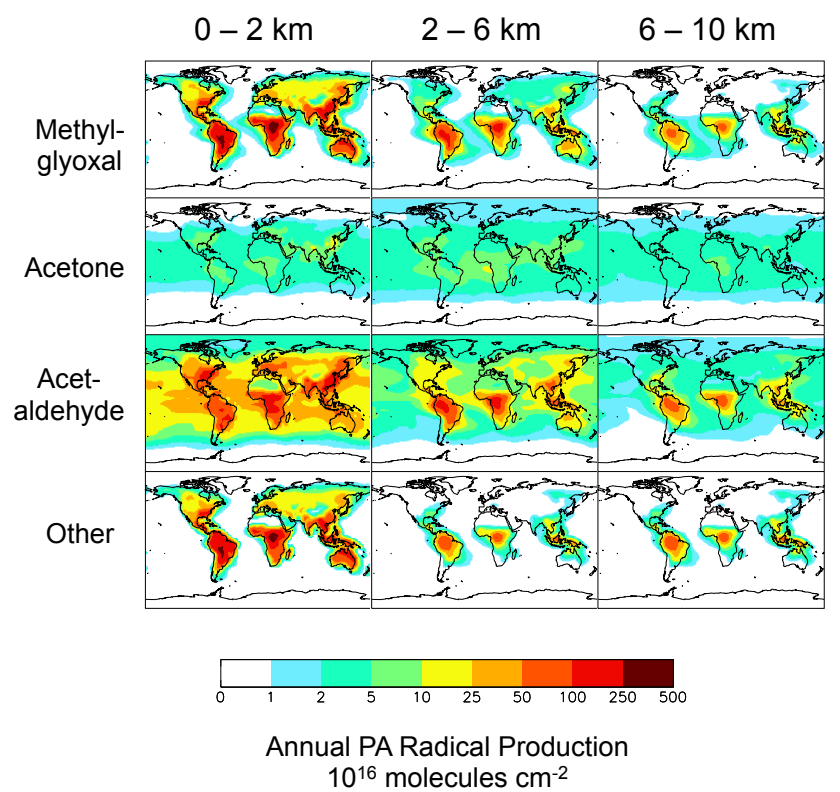

Fig. 6. Annual total PA radical production for three altitude ranges contributed by the immediate precursors methylglyoxal, acetone, and acetaldehyde. The other precursors include a number of species produced in the oxidation of isoprene.

al. (2009a, b) oxidation scheme in GEOS-Chem improves the simulation of summertime observations over the southeastern US (Mao et al., 2013b). It also substantially increases surface PAN mixing ratios over the Amazon and central Africa, where there are very few observational data (Angelo, 2012). In these regions surface PAN increases by $100-300$ pptv with the Paulot et al. (2009a, b) scheme, but the impact is more

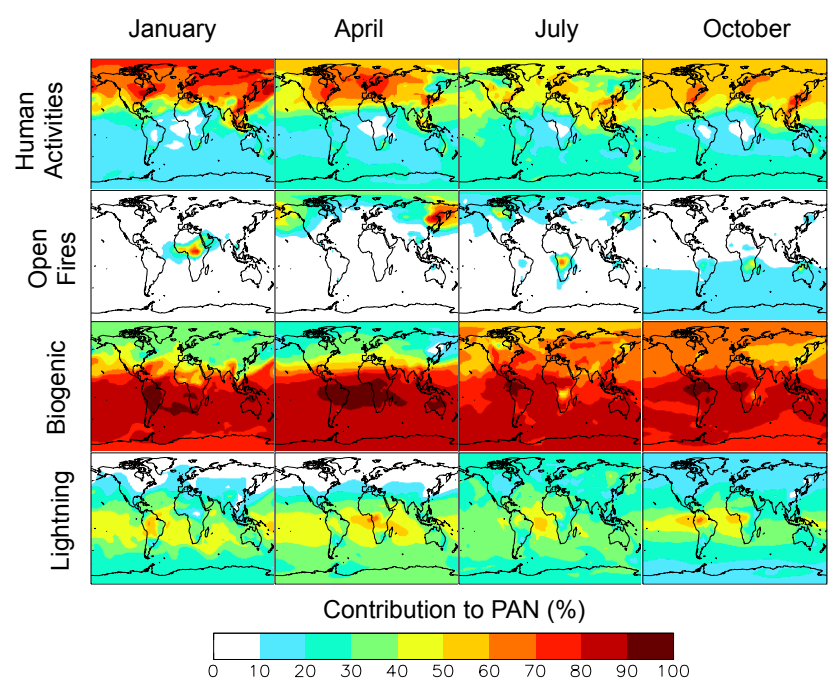

Fig. 7. Sensitivity of PAN to different emission types. Results are shown as relative decreases of monthly mean total PAN columns in sensitivity simulations with individual emission types shut off. Biogenic signifies NMVOCs only.

modest above the boundary layer, generally less than $50 \mathrm{pptv}$. In the model, most of the free-tropospheric PAN in convective regions is produced above the boundary layer.

\section{Contributions from different source types to PAN formation}

Figure 7 presents the sensitivity of PAN concentrations to different emission types, as diagnosed by the relative 
decrease in a sensitivity simulation with that emission type shut off. Contributions do not add up to $100 \%$ because of nonlinearity.

During Northern Hemisphere spring, shutting off anthropogenic emissions decreases the integrated PAN burden by $\sim 50 \%$. Alkanes are the most important class of anthropogenic NMVOC precursors for PAN in northern midlatitudes. Their role is more important in spring when NMVOC emissions from the biosphere are smaller. In spring, the time of the surface PAN maximum, biogenic and anthropogenic NMVOCs species each support $\sim 50 \%$ of the PAN burden.

Though most biomass burning occurs primarily in the tropics, the effect of fires on PAN appears to be largest at northern latitudes. Shutting off emissions from springtime fires located in Russia and China decreases the hemispheric burden by $\sim 25 \%$, but the decrease in PAN mixing ratios is $30-40 \%$ at high latitudes. These springtime fires, which exhibit strong variability in magnitude and location, contribute to the observed spring PAN maximum. Russian fires likely accentuated this feature in April 2008, an unusually strong fire season (Vivchar, 2010; Warneke et al., 2009, 2010). PAN in fire plumes from the Russian Federation was shown to support efficient $\mathrm{O}_{3}$ production over the northeast Pacific during April 2008 (Fischer et al., 2010). Enhancements in $\mathrm{O}_{3}$ of up to $20 \mathrm{ppbv}$ were observed during this time from Alaska to California (Oltmans et al., 2010). Spring 2008 was an extreme burning year, but Macdonald et al. (2011) also attribute elevated monthly mean $\mathrm{O}_{3}$ concentrations at Whistler Mountain, BC, in fall 2002 and spring 2003 to fires in the Russian Federation.

As stated earlier, the treatment of PAN formation in fires plays an important role in determining the global impact of this PAN source. Past model studies have found that reproducing observed free-tropospheric $\mathrm{CO}$ and $\mathrm{O}_{3}$ downwind from boreal fires requires injecting a fraction of the emissions above the boundary layer (Leung et al., 2007; Turquety et al., 2007; Generoso et al., 2007; Colarco et al., 2004). Tereszchuk et al. (2013) show that PAN in the upper troposphere at high latitudes is mainly from large boreal fires in summer. Emitting a fraction of the smoke above the boundary layer is an important model update that improves the simulation of the $2-6 \mathrm{~km}$ PAN reservoir at high latitudes. The fraction of $\mathrm{NO}_{\mathrm{x}}$ in the springtime Russian fires that is immediately partitioned to PAN also has a large impact on springtime PAN over high latitudes because PAN has a long lifetime during this season. The combination of model updates chosen here best reproduces the evolution of the springtime PAN profile as observed during TOPSE (Wang et al., 2003). Specifically, PAN remains relatively constant (150-200 pptv) with altitude in February and March, and the 2-6 km PAN reservoir forms in April. Springtime PAN in the model is acutely sensitive to the amount of $\mathrm{NO}_{\mathrm{x}}$ that is immediately partitioned to PAN in fires. Given that $\mathrm{O}_{3}$ production in the Arctic lower troposphere is sensitive to the abundance of PAN (Walker et al., 2012; Beine et al., 1997), more work is warranted to determine the best way to incorporate the chemistry that rapidly produces PAN in fires.

We find that biogenic species drive PAN production in summer and fall. From June to October, shutting off biogenic emissions decreases the Northern Hemisphere integrated PAN burden by $\sim 75 \%$. In summer, the contribution to PAN from other biogenic NMVOCs (terpenes, acetone, acetaldehyde, ethanol and higher alkenes) is $~ 50 \%$ that of isoprene. Consistent with our analysis, Roberts et al. (2006) estimated that the isoprene contribution to PAN formation is 1.6 to 4 times larger than the anthropogenic NMVOC contribution in the northeastern US in summer.

The austral spring mid-upper-tropospheric PAN maximum (> 400 pptv) spanning the Atlantic (Fig. 2) is also apparent in MIPAS PAN retrievals (Glatthor et al., 2007; Moore and Remedios, 2010; Wiegele et al., 2012). Figure 7 shows that this feature is more sensitive to emissions of $\mathrm{NO}_{\mathrm{x}}$ from lightning than emissions from either biomass burning or anthropogenic sources. Biomass burning takes place from July to October in the part of Africa located in the Southern Hemisphere. Singh et al. (1996a) found that PAN correlated with tracers of biomass combustion in the eastern South Atlantic in the lower and middle troposphere, but not in the upper troposphere. To explain observed $\mathrm{NO}_{\mathrm{x}}$ at higher altitudes, they had to invoke a large contribution from lightning (Smyth et al., 1996). Our simulation reproduces the TRACE-A vertical PAN profiles for the South Atlantic (Supplement Fig. 1, panels 43-45) and the correlation between PAN and CO (not shown). We find that fires are responsible for approximately $30 \%$ of the PAN over the tropical Atlantic between 2 and $4 \mathrm{~km}$. Above $6 \mathrm{~km}$, the contribution from fires is small. In the upper troposphere, the oxidation of biogenic NMVOCs (lifted by convection (Murphy et al., 2010; Bechara et al., 2010; Warneke et al., 2001)) in the presence of lightning $\mathrm{NO}_{\mathrm{x}}$ is a large source of PAN (Tie et al., 2001; Labrador et al., 2005). Compared to the previous version of GEOSChem, the sensitivity of upper-tropospheric PAN to lightning is reduced by $30 \%$. We attribute this change to increased $\mathrm{OH}$ in the boundary layer through the use of the Paulot et al. $(2009 \mathrm{a}, \mathrm{b})$ isoprene scheme, which reduces the amount of NMVOC injected into the free troposphere (Paulot et al., 2012). Boundary layer and upper-tropospheric chemistry in the tropics are tightly coupled (Paulot et al., 2012). Hence the simulation of upper-tropospheric PAN is sensitive to the representation of boundary layer chemistry, which remains very uncertain (Hewitt et al., 2010).

\section{Conclusions}

We utilized a worldwide collection of observations to improve a global simulation of PAN in the GEOS-Chem model. This new simulation, which includes an improved representation of numerous NMVOCs and a different treatment of biomass burning emissions, affords the opportunity to 
understand the factors driving the PAN distribution on the global scale.

1. We find that PAN is generally more sensitive to NMVOC emissions than $\mathrm{NO}_{\mathrm{x}}$ emissions. In many regions of the atmosphere, changes to NMVOC emissions produce a supra-linear change in PAN through feedbacks to remote $\mathrm{NO}_{\mathrm{x}}$ and $\mathrm{O}_{3}$ budgets. A different mixture of NMVOCs supports PAN formation in each region and season. Considerable improvement of the PAN simulation for the Asian outflow region is achieved by including aromatics. Our results stress the need for global CTMs, which can yield different results for PAN (Singh et al., 2007), to include and evaluate budgets for many NMVOCs that are routinely ignored.

2. In order to reproduce the observed PAN reservoir at 3-6 km over high northern latitudes, we have changed the way emissions from fires are incorporated into the model. We increased the simulated PAN reservoir over high latitudes by (1) adding biomass burning emissions of shorter-lived NMVOCs (monoterpenes, aromatics), (2) emitting a fraction of the biomass burning $\mathrm{NO}_{\mathrm{x}}$ directly as PAN (Alvarado et al., 2010), (3) emitting a portion of the smoke above the boundary layer, (4) updating the emission factors for NMVOCs and $\mathrm{NO}_{\mathrm{x}}$ (Akagi et al., 2011), and (5) increasing emissions to account for undetected small fires at high latitudes (Kaiser et al., 2012). We find that PAN over the Arctic is very sensitive to fires, and particularly sensitive to the amount of $\mathrm{NO}_{\mathrm{x}}$ that is immediately partitioned to PAN in fires and to the altitude of the emissions. Given that $\mathrm{O}_{3}$ production in the Arctic lower troposphere is very sensitive to $\mathrm{NO}_{\mathrm{x}}$ abundance (Stroud et al., 2004; Walker et al., 2012), more work is warranted to determine the best way to incorporate the plume chemistry that rapidly produces PAN into CTMs.

3. The principal carbonyl precursors of PAN are acetaldehyde ( $44 \%$ of the global source), methylglyoxal $(30 \%)$ and acetone $(7 \%)$. Acetaldehyde is produced by a large suite of NMVOCs and also directly emitted. Methylglyoxal is mostly from isoprene. Isoprene oxidation products, other than methylglyoxal, are also significant. With updated (lower) photolysis yields, acetone is a substantially less important pathway for PAN formation than previously thought (Singh et al., 1995).

4. Isoprene accounts for $37 \%$ of the global PAN burden. Many other NMVOC emissions contribute to the balance, with no single species contributing more than $10 \%$ (Table 1). At Northern Hemisphere midlatitudes, alkanes contribute to a third of PAN formation during the springtime maximum.
5. A springtime upper troposphere PAN maximum across the tropical Atlantic is the major feature of the Southern Hemisphere PAN distribution. Lightning is the most important $\mathrm{NO}_{\mathrm{x}}$ source for PAN formation in this region of the atmosphere. A cascade of isoprene oxidation products, delivered to the upper troposphere by deep convection, provides the PA radical source. This finding is sensitive to the description of boundary layer chemistry under low- $\mathrm{NO}_{\mathrm{x}}$ conditions.

The work presented here has increased confidence in our ability to simulate the observed distribution of PAN within the GEOS-Chem CTM. In a follow-up paper we will examine the importance of PAN in affecting global tropospheric $\mathrm{O}_{3}$ and $\mathrm{OH}$, and the implications for intercontinental transport of pollution, the oxidizing power of the atmosphere, and climate forcing.

\section{Supplementary material related to this article is available online at http://www.atmos-chem-phys.net/14/ 2679/2014/acp-14-2679-2014-supplement.pdf.}

Acknowledgements. This work was supported by the NASA Atmospheric Composition Modeling and Analysis Program. Support for E. V. Fischer was provided by the NOAA Climate and Global Change Postdoctoral Fellowship Program, administered by UCAR, and by a Harvard University Center for the Environment Postdoctoral Fellowship. The contribution of PAN data from the GAW Global Station Hohenbeissenberg by Stefan Gilge, German Meteorological Service, is greatly acknowledged. The contribution of PAN data from the Jungfraujoch Mountain Site by Christoph Zellweger (EMPA) is greatly acknowledged. We thank Hiroshi Tanimoto for providing the data from Rishiri, Japan. Pico PAN data were collected under the leadership of Richard Honrath with funding from the National Science Foundation grant ATM-0720955. Funding for the analysis of the Pico PAN measurements by Katja Dzepina, Jim Roberts and Lynn Mazzoleni was provided by the National Science Foundation through grant AGS-1110059. We also appreciate the contribution of unpublished PAN data from the Thompson Farm AIRMAP Site by Ryan Chartier. Finally, we thank Martin Steinbacher and Jim Roberts for helpful comments on the manuscript.

Edited by: A. Pozzer

\section{References}

Akagi, S. K., Yokelson, R. J., Wiedinmyer, C., Alvarado, M. J., Reid, J. S., Karl, T., Crounse, J. D., and Wennberg, P. O.: Emission factors for open and domestic biomass burning for use in atmospheric models, Atmos. Chem. Phys., 11, 4039-4072, doi:10.5194/acp-11-4039-2011, 2011.

Alvarado, M. J., Logan, J. A., Mao, J., Apel, E., Riemer, D., Blake, D., Cohen, R. C., Min, K. E., Perring, A. E., Browne, E. C., Wooldridge, P. J., Diskin, G. S., Sachse, G. W., Fuelberg, H., 
Sessions, W. R., Harrigan, D. L., Huey, G., Liao, J., Case-Hanks, A., Jimenez, J. L., Cubison, M. J., Vay, S. A., Weinheimer, A. J., Knapp, D. J., Montzka, D. D., Flocke, F. M., Pollack, I. B., Wennberg, P. O., Kurten, A., Crounse, J., Clair, J. M. S., Wisthaler, A., Mikoviny, T., Yantosca, R. M., Carouge, C. C., and Le Sager, P.: Nitrogen oxides and PAN in plumes from boreal fires during ARCTAS-B and their impact on ozone: an integrated analysis of aircraft and satellite observations, Atmos. Chem. Phys., 10, 9739-9760, doi:10.5194/acp-10-9739-2010, 2010.

Angelo, C.: Amazon fire analysis hits new heights, Nature News, doi:10.1038/nature.2012.11467, 2012.

Atkinson, R. and Arey, J.: Gas-phase tropospheric chemistry of biogenic volatile organic compounds: a review, Atmos. Environ., 37 Supplement No. 2, S197-S219, 2003.

Atlas, E. L., Ridley, B. A., and Cantrell, C. A.: The Tropospheric Ozone Production about the Spring Equinox (TOPSE) Experiment: Introduction, J. Geophys. Res., 108, 8353, doi:10.1029/2002jd003172, 2003.

Balzani Loov, J. M., Henne, S., Legreid, G., Staehelin, J., Reimann, S., Prevut, A. S. H., Steinbacher, M., and Vollmer, M. K.: Estimation of background concentrations of trace gases at the Swiss Alpine site Jungfraujoch (3580 m asl), J. Geophys. Res., 113, D22305, doi:10.1029/2007jd009751, 2008.

Barletta, B., Meinardi, S., Simpson, I. J., Sherwood Rowland, F., Chan, C.-Y., Wang, X., Zou, S., Chan, L. Y., and Blake, D. R.: Ambient halocarbon mixing ratios in 45 Chinese cities, Atmos. Environ., 40, 7706-7719, doi:10.1016/j.atmosenv.2006.08.039, 2006.

Bechara, J., Borbon, A., Jambert, C., Colomb, A., and Perros, P. E.: Evidence of the impact of deep convection on reactive Volatile Organic Compounds in the upper tropical troposphere during the AMMA experiment in West Africa, Atmos. Chem. Phys., 10, 10321-10334, doi:10.5194/acp-10-10321-2010, 2010.

Beine, H., Jaffe, D., Herring, J., Kelley, J., Krognes, T., and Stordal, F.: High-Latitude Springtime Photochemistry. Part I: $\mathrm{NO}_{\mathrm{x}}$, PAN and Ozone Relationships, J. Atmos. Chem., 27, 127153, doi:10.1023/a:1005869900567, 1997.

Beine, H. J. and Krognes, T.: The seasonal cycle of peroxyacetyl nitrate (PAN) in the European Arctic, Atmos. Environ., 34, 933940, doi:10.1016/s1352-2310(99)00288-5, 2000.

Beine, H. J., Jaffe, D. A., Blake, D. R., Atlas, E., and Harris, J.: Measurements of PAN, alkyl nitrates, ozone, and hydrocarbons during spring in interior Alaska, J. Geophys. Res., 101, 1261312619, doi:10.1029/96jd00342, 1996.

Bertram, T. H., Perring, A. E., Wooldridge, P. J., Crounse, J. D., Kwan, A. J., Wennberg, P. O., Scheuer, E., Dibb, J., Avery, M., Sachse, G., Vay, S. A., Crawford, J. H., McNaughton, C. S., Clarke, A., Pickering, K. E., Fuelberg, H., Huey, G., Blake, D. R., Singh, H. B., Hall, S. R., Shetter, R. E., Fried, A., Heikes, B. G., and Cohen, R. C.: Direct Measurements of the Convective Recycling of the Upper Troposphere, Science, 315, 816-820, doi:10.1126/science.1134548, 2007.

Bertram, T. H., Perring, A. E., Wooldridge, P. J., Dibb, J., Avery, M. A., and Cohen, R. C.: On the export of reactive nitrogen from Asia: $\mathrm{NO}_{\mathrm{x}}$ partitioning and effects on ozone, Atmos. Chem. Phys., 13, 4617-4630, doi:10.5194/acp-13-4617-2013, 2013.

Bey, I., Jacob, D. J., Yantosca, R. M., Logan, J. A., Field, B. D., Fiore, A. M., Li, Q., Liu, H. Y., Mickley, L. J., and Schultz, M. G.: Global modeling of tropospheric chemistry with assimilated meteorology: Model description and evaluation, J. Geophys. Res., 106, 23073-23095, doi:10.1029/2001jd000807, 2001.

Bloss, C., Wagner, V., Jenkin, M. E., Volkamer, R., Bloss, W. J., Lee, J. D., Heard, D. E., Wirtz, K., Martin-Reviejo, M., Rea, G., Wenger, J. C., and Pilling, M. J.: Development of a detailed chemical mechanism (MCMv3.1) for the atmospheric oxidation of aromatic hydrocarbons, Atmos. Chem. Phys., 5, 641-664, doi:10.5194/acp-5-641-2005, 2005.

Bottenheim, J. W., Gallant, A. G., and Brice, K. A.: Measurements of $\mathrm{NO}_{Y}$ species and $\mathrm{O}_{3}$ at $82^{\circ} \mathrm{N}$ latitude, Geophys. Res. Lett, 13, 113-116, doi:10.1029/GL013i002p00113, 1986.

Bottenheim, J. W., Sirois, A., Brice, K. A., and Gallant, A. J.: Five years of continuous observations of PAN and ozone at a rural location in eastern Canada, J. Geophys. Res., 99, 5333-5352, doi:10.1029/93jd02716, 1994.

Brice, K. A., Bottenheim, J. W., Anlauf, K. G., and Wiebe, H. A.: Long-term measurements of atmospheric peroxyacetylnitrate (PAN) at rural sites in Ontario and Nova Scotia; seasonal variations and long-range transport, Tellus B, 40B, 408-425. 1988.

Bridier, I., Caralp, F., Loirat, H., Lesclaux, R., Veyret, B., Becker, K. H., Reimer, A., and Zabel, F.: Kinetic and theoretical studies of the reactions of acetylperoxy + nitrogen dioxide $+M<-$ $>$ acetyl peroxynitrate $+\mathrm{M}$ between 248 and $393 \mathrm{~K}$ and between 30 and 760 torr, J. Phys. Chem., 95, 3594-3600, doi:10.1021/j100162a031, 1991.

Carpenter, L. J., Green, T. J., Mills, G. P., Bauguitte, S., Penkett, S. A., Zanis, P., Schuepbach, E., Schmidbauer, N., Monks, P. S., and Zellweger, C.: Oxidized nitrogen and ozone production efficiencies in the springtime free troposphere over the Alps, J. Geophys. Res., 105, 14547-14559, doi:10.1029/2000jd900002, 2000.

Colarco, P. R., Schoeberl, M. R., Doddridge, B. G., Marufu, L. T., Torres, O., and Welton, E. J.: Transport of smoke from Canadian forest fires to the surface near Washington, D.C.: Injection height, entrainment, and optical properties, J. Geophys. Res., 109, D06203, doi:10.1029/2003jd004248, 2004.

Dassau, T. M., Shepson, P. B., Bottenheim, J. W., and Ford, K. M.: Peroxyacetyl nitrate photochemistry and interactions with the Arctic surface, J. Geophys. Res., 109, D18302, doi:10.1029/2004jd004562, 2004.

Fischer, E. V., Jaffe, D. A., Reidmiller, D. R., and Jaegle, L.: Meteorological controls on observed peroxyacetyl nitrate at Mount Bachelor during the spring of 2008, J. Geophys. Res., 115, D03302, doi:10.1029/2009jd012776, 2010.

Fischer, E. V., Jaffe, D. A., and Weatherhead, E. C.: Free tropospheric peroxyacetyl nitrate (PAN) and ozone at Mount Bachelor: causes of variability and timescale for trend detection, Atmos. Chem. Phys. 11, 5641-5654, doi:10.5194/acp-11-56412011, 2011.

Fischer, E. V., Jacob, D. J., Millet, D. B., Yantosca, R. M., and Mao, J.: The role of the ocean in the global atmospheric budget of acetone, Geophys. Res. Lett., 39, L01807, doi:10.1029/2011g1050086, 2012.

Flocke, F., Weinheimer, A., Swanson, A., Roberts, J., Schmitt, R., and Shertz, S.: On the Measurement of PANs by Gas Chromatography and Electron Capture Detection, J. Atmos. Chem., 52, 1943, doi:10.1007/s10874-005-6772-0, 2005.

Ford, K. M., Campbell, B. M., Shepson, P. B., Bertman, S. B., Honrath, R. E., Peterson, M., and Dibb, J. E.: Studies of Peroxyacetyl nitrate (PAN) and its interaction with the snow- 
pack at Summit, Greenland, J. Geophys. Res., 107, 4102, doi:10.1029/2001jd000547, 2002.

Fu, T.-M., Jacob, D. J., Palmer, P. I., Chance, K., Wang, Y. X., Barletta, B., Blake, D. R., Stanton, J. C., and Pilling, M. J.: Space-based formaldehyde measurements as constraints on volatile organic compound emissions in east and south Asia and implications for ozone, J. Geophys. Res., 112, D06312, doi:10.1029/2006jd007853, 2007.

Fu, T.-M., Jacob, D. J., Wittrock, F., Burrows, J. P., Vrekoussis, M., and Henze, D. K.: Global budgets of atmospheric glyoxal and methylglyoxal, and implications for formation of secondary organic aerosols, J. Geophys. Res., 113, D15303, doi:10.1029/2007JD009505, 2008.

Galloway, M. M., Huisman, A. J., Yee, L. D., Chan, A. W. H., Loza, C. L., Seinfeld, J. H., and Keutsch, F. N.: Yields of oxidized volatile organic compounds during the $\mathrm{OH}$ radical initiated oxidation of isoprene, methyl vinyl ketone, and methacrolein under high- $\mathrm{NO}_{\mathrm{x}}$ conditions, Atmos. Chem. Phys. 11, 10779-10790, doi:10.5194/acp-11-10779-2011, 2011.

Generoso, S., Bey, I., Attié, J.-L., and Bréon, F.-M.: A satelliteand model-based assessment of the 2003 Russian fires: Impact on the Arctic region, J. Geophys. Res., 112, D15302, doi:10.1029/2006jd008344, 2007.

Glatthor, N., von Clarmann, T., Fischer, H., Funke, B., Grabowski, U., Hopfner, M., Kellmann, S., Kiefer, M., Linden, A., Milz, M., Steck, T., and Stiller, G. P.: Global peroxyacetyl nitrate (PAN) retrieval in the upper troposphere from limb emission spectra of the Michelson Interferometer for Passive Atmospheric Sounding (MIPAS), Atmos. Chem. Phys., 7, 2775-2787, doi:10.5194/acp7-2775-2007, 2007.

Goliff, W. S., Stockwell, W. R., and Lawson, C. V.: The regional atmospheric chemistry mechanism, version 2, Atmos. Environ., 68, 174-185, doi:10.1016/j.atmosenv.2012.11.038, 2013.

Grosjean, D., Grosjean, E., and Williams, E. L.: Thermal Decomposition of PAN, PPN and Vinyl-PAN, Air Waste, 44, 391-396, doi:10.1080/1073161x.1994.10467260, 1994.

Guenther, A., Karl, T., Harley, P., Wiedinmyer, C., Palmer, P. I., and Geron, C.: Estimates of global terrestrial isoprene emissions using MEGAN (Model of Emissions of Gases and Aerosols from Nature), Atmos. Chem. Phys., 6, 3181-3210, doi:10.5194/acp-63181-2006, 2006.

Hewitt, C. N., Lee, J. D., MacKenzie, A. R., Barkley, M. P., Carslaw, N., Carver, G. D., Chappell, N. A., Coe, H., Collier, C., Commane, R., Davies, F., Davison, B., DiCarlo, P., Di Marco, C. F., Dorsey, J. R., Edwards, P. M., Evans, M. J., Fowler, D., Furneaux, K. L., Gallagher, M., Guenther, A., Heard, D. E., Helfter, C., Hopkins, J., Ingham, T., Irwin, M., Jones, C., Karunaharan, A., Langford, B., Lewis, A. C., Lim, S. F., MacDonald, S. M., Mahajan, A. S., Malpass, S., McFiggans, G., Mills, G., Misztal, P., Moller, S., Monks, P. S., Nemitz, E., Nicolas-Perea, V., Oetjen, H., Oram, D. E., Palmer, P. I., Phillips, G. J., Pike, R., Plane, J. M. C., Pugh, T., Pyle, J. A., Reeves, C. E., Robinson, N. H., Stewart, D., Stone, D., Whalley, L. K., and Yin, X.: Overview: oxidant and particle photochemical processes above a south-east Asian tropical rainforest (the OP3 project): introduction, rationale, location characteristics and tools, Atmos. Chem. Phys., 10, 169-199, doi:10.5194/acp-10-169-2010, 2010.

Horowitz, L. W., Liang, J., Gardner, G. M., and Jacob, D. J.: Export of reactive nitrogen from North America during summer- time: Sensitivity to hydrocarbon chemistry, J. Geophys. Res, 103, 13451-13476, doi:10.1029/97jd03142, 1998.

Hudman, R. C., Jacob, D. J., Cooper, O. R., Evans, M. J., Heald, C. L., Park, R. J., Fehsenfeld, F., Flocke, F., Holloway, J., Hübler, G., Kita, K., Koike, M., Kondo, Y., Neuman, A., Nowak, J., Oltmans, S., Parrish, D., Roberts, J. M., and Ryerson, T.: Ozone production in transpacific Asian pollution plumes and implications for ozone air quality in California, J. Geophys. Res., 109, D23S10, doi:10.1029/2004jd004974, 2004.

Hudman, R. C., Jacob, D. J., Turquety, S., Leibensperger, E. M., Murray, L. T., Wu, S., Gilliland, A. B., Avery, M., Bertram, T. H., Brune, W., Cohen, R. C., Dibb, J. E., Flocke, F. M., Fried, A., Holloway, J., Neuman, J. A., Orville, R., Perring, A., Ren, X., Sachse, G. W., Singh, H. B., Swanson, A., and Wooldridge, P. J.: Surface and lightning sources of nitrogen oxides over the United States: Magnitudes, chemical evolution, and outflow, J. Geophys. Res., 112, D12S05, doi:10.1029/2006jd007912, 2007.

Ito, A., Sillman, S., and Penner, J. E.: Effects of additional nonmethane volatile organic compounds, organic nitrates, and direct emissions of oxygenated organic species on global tropospheric chemistry, J. Geophys. Res., 112, D06309, doi:10.1029/2005jd006556, 2007.

Jacob, D. J.: Heterogeneous chemistry and tropospheric ozone, Atmos. Environ., 34, 2131-2159, 2000.

Jacob, D. J., Wofsy, S. C., Bakwin, P. S., Fan, S. M., Harriss, R. C., Talbot, R. W., Bradshaw, J. D., Sandholm, S. T., Singh, H. B., Browell, E. V., Gregory, G. L., Sachse, G. W., Shipham, M. C., Blake, D. R., and Fitzjarrald, D. R.: Summertime photochemistry of the troposphere at high northern latitudes, J. Geophys. Res, 97, 16421-16431, doi:10.1029/91jd01968, 1992.

Jacobi, H. W., Weller, R., Bluszcz, T., and Schrems, O.: Latitudinal distribution of peroxyacetyl nitrate (PAN) over the Atlantic Ocean, J. Geophys. Res., 104, 26901-26912, doi:10.1029/1999jd900462, 1999.

Jaffe, D. A., Berntsen, T. K., and Isaksen, I. S. A.: A global threedimensional chemical transport model 2. Nitrogen oxides and nonmethane hydrocarbon results, J. Geophys. Res., 102, 2128121296, doi:10.1029/96jd03400, 1997.

Kaiser, J. W., Heil, A., Andreae, M. O., Benedetti, A., Chubarova, N., Jones, L., Morcrette, J. J., Razinger, M., Schultz, M. G., Suttie, M., and van der Werf, G. R.: Biomass burning emissions estimated with a global fire assimilation system based on observed fire radiative power, Biogeosci., 9, 527-554, doi:10.5194/bg-9527-2012, 2012.

Kasibhatla, P. S., Levy, H., and Moxim, W. J.: Global $\mathrm{NO}_{\mathrm{x}}$, $\mathrm{HNO}_{3}, \mathrm{PAN}$, and $\mathrm{NO}_{\mathrm{y}}$ distributions from fossil fuel combustion emissions: A model study, J. Geophys. Res, 98, 7165-7180, doi:10.1029/92jd02845, 1993.

Kotchenruther, R. A., Jaffe, D. A., and Jaeglé, L.: Ozone photochemistry and the role of peroxyacetyl nitrate in the springtime northeastern Pacific troposphere: Results from the Photochemical Ozone Budget of the Eastern North Pacific Atmosphere (PHOBEA) campaign, J. Geophys. Res., 106, 2873128742, doi:10.1029/2000jd000060, 2001.

Kuhns, H., Green, M., and Etyemezian, V.: Big Bend Regional Aerosol and Visibility Observational (BRAVO) Study Emissions Inventory, Desert Research Institute, Las Vegas, NV, 2003.

Labrador, L. J., von Kuhlmann, R., and Lawrence, M. G.: The effects of lightning-produced $\mathrm{NO}_{\mathrm{x}}$ and its vertical distribution 
on atmospheric chemistry: sensitivity simulations with MATCHMPIC, Atmos. Chem. Phys., 5, 1815-1834, doi:10.5194/acp-51815-2005, 2005.

Lelieveld, J., Butler, T. M., Crowley, J. N., Dillon, T. J., Fischer, H., Ganzeveld, L., Harder, H., Lawrence, M. G., Martinez, M., Taraborrelli, D., and Williams, J.: Atmospheric oxidation capacity sustained by a tropical forest, Nature, 452, 737-740, 2008.

Leung, F.-Y. T., Logan, J. A., Park, R., Hyer, E., Kasischke, E., Streets, D., and Yurganov, L.: Impacts of enhanced biomass burning in the boreal forests in 1998 on tropospheric chemistry and the sensitivity of model results to the injection height of emissions, J. Geophys. Res., 112, D10313, doi:10.1029/2006jd008132, 2007.

Liang, Q., Rodriguez, J. M., Douglass, A. R., Crawford, J. H., Olson, J. R., Apel, E., Bian, H., Blake, D. R., Brune, W., Chin, M., Colarco, P. R., da Silva, A., Diskin, G. S., Duncan, B. N., Huey, L. G., Knapp, D. J., Montzka, D. D., Nielsen, J. E., Pawson, S., Riemer, D. D., Weinheimer, A. J., and Wisthaler, A.: Reactive nitrogen, ozone and ozone production in the Arctic troposphere and the impact of stratosphere-troposphere exchange, Atmos. Chem. Phys., 11, 13181-13199, doi:10.5194/acp-11-13181-2011, 2011.

Liu, Z., Wang, Y., Gu, D., Zhao, C., Huey, L. G., Stickel, R., Liao, J., Shao, M., Zhu, T., Zeng, L., Liu, S.-C., Chang, C.-C., Amoroso, A., and Costabile, F.: Evidence of Reactive Aromatics As a Major Source of Peroxy Acetyl Nitrate over China, Environ. Sci. Tech., 44, 7017-7022, doi:10.1021/es1007966, 2010.

Lurmann, F. W., Lloyd, A. C., and Atkinson, R.: A Chemical Mechanism for Use in Long-Range Transport/Acid Deposition Computer Modeling, J. Geophys. Res., 91, 10905-10936, doi:10.1029/JD091iD10p10905, 1986.

Macdonald, A. M., Anlauf, K. G., Leaitch, W. R., Chan, E., and Tarasick, D. W.: Interannual variability of ozone and carbon monoxide at the Whistler high elevation site: 2002-2006, Atmos. Chem. Phys., 11, 11431-11446, doi:10.5194/acp-1111431-2011, 2011.

Maloney, J. C., Fuelberg, H. E., Avery, M. A., Crawford, J. H., Blake, D. R., Heikes, B. G., Sachse, G. W., Sandholm, S. T., Singh, H., and Talbot, R. W.: Chemical characteristics of air from different source regions during the second Pacific Exploratory Mission in the Tropics (PEM-Tropics B), J. Geophys. Res., 106, 32609-32625, doi:10.1029/2001jd900100, 2001.

Mao, J., Jacob, D. J., Evans, M. J., Olson, J. R., Ren, X., Brune, W. H., Clair, J. M. S., Crounse, J. D., Spencer, K. M., Beaver, M. R., Wennberg, P. O., Cubison, M. J., Jimenez, J. L., Fried, A., Weibring, P., Walega, J. G., Hall, S. R., Weinheimer, A. J., Cohen, R. C., Chen, G., Crawford, J. H., McNaughton, C., Clarke, A. D., Jaegle, L., Fisher, J. A., Yantosca, R. M., Le Sager, P., and Carouge, C.: Chemistry of hydrogen oxide radicals $\left(\mathrm{HO}_{\mathrm{x}}\right)$ in the Arctic troposphere in spring, Atmos. Chem. Phys., 10, 58235838, doi:10.5194/acp-10-5823-2010, 2010.

Mao, J., Ren, X., Zhang, L., Van Duin, D. M., Cohen, R. C., Park, J. H., Goldstein, A. H., Paulot, F., Beaver, M. R., Crounse, J. D., Wennberg, P. O., DiGangi, J. P., Henry, S. B., Keutsch, F. N., Park, C., Schade, G. W., Wolfe, G. M., Thornton, J. A., and Brune, W. H.: Insights into hydroxyl measurements and atmospheric oxidation in a California forest, Atmos. Chem. Phys., 12, 8009-8020, doi:10.5194/acp-12-8009-2012, 2012.

Mao, J., Fan, S., Jacob, D. J., and Travis, K. R.: Radical loss in the atmosphere from $\mathrm{Cu}-\mathrm{Fe}$ redox coupling in aerosols, At- mos. Chem. Phys., 13, 509-519, doi:10.5194/acp-13-509-2013, 2013a.

Mao, J., Paulot, F., Jacob, D. J., Cohen, R. C., Crounse, J. D., Wennberg, P. O., Keller, C. A., Hudman, R. C., Barkley, M. P., and Horowitz, L. W.: Ozone and organic nitrates over the eastern United States: Sensitivity to isoprene chemistry, J. Geophys. Res. Atmos., 118, 11256-11268, doi:10.1002/jgrd.50817, 2013b.

Marais, E. A., Jacob, D. J., Kurosu, T. P., Chance, K., Murphy, J. G., Reeves, C., Mills, G., Casadio, S., Millet, D. B., Barkley, M. P., Paulot, F., and Mao, J.: Isoprene emissions in Africa inferred from OMI observations of formaldehyde columns, Atmos. Chem. Phys. Discuss., 12, 7475-7520, doi:10.5194/acpd12-7475-2012, 2012.

Marecal, V., Pirre, M., Rivire, E. D., Pouvesle, N., Crowley, J. N., Freitas, S. R., and Longo, K. M.: Modelling the reversible uptake of chemical species in the gas phase by ice particles formed in a convective cloud, Atmos. Chem. Phys., 10, 4977-5000, doi:10.5194/acp-10-4977-2010, 2010.

McFadyen, G. G. and Cape, J. N.: Peroxyacetyl nitrate in eastern Scotland, Sci. Total Environ., 337, 213-222, 2005.

Millet, D. B., Guenther, A., Siegel, D. A., Nelson, N. B., Singh, H. B., de Gouw, J. A., Warneke, C., Williams, J., Eerdekens, G., Sinha, V., Karl, T., Flocke, F., Apel, E., Riemer, D. D., Palmer, P. I., and Barkley, M.: Global atmospheric budget of acetaldehyde: 3-D model analysis and constraints from in-situ and satellite observations, Atmos. Chem. Phys., 10, 3405-3425, doi:10.5194/acp-10-3405-2010, 2010.

Mitovski, T., Folkins, I., Martin, R. V., and Cooper, M.: Testing convective transport on short time scales: Comparisons with mass divergence and ozone anomaly patterns about high rain events, J. Geophys. Res., 117, D02109, doi:10.1029/2011jd016321, 2012.

Moore, D. P. and Remedios, J. J.: Seasonality of Peroxyacetyl nitrate (PAN) in the upper troposphere and lower stratosphere using the MIPAS-E instrument, Atmos. Chem. Phys., 10, 6117-6128, doi:10.5194/acp-10-6117-2010, 2010.

Moxim, W. J., Levy, H., II, and Kasibhatla, P. S.: Simulated global tropospheric PAN: Its transport and impact on $\mathrm{NO}_{\mathrm{x}}, \mathrm{J}$. Geophys. Res., 101, 12621-12638, doi:10.1029/96JD00338, 1996.

Murphy, J. G., Oram, D. E., and Reeves, C. E.: Measurements of volatile organic compounds over West Africa, Atmos. Chem. Phys., 10, 5281-5294, doi:10.5194/acp-10-5281-2010, 2010.

Murray, L. T., Jacob, D. J., Logan, J. A., Hudman, R. C., and Koshak, W. J.: Optimized regional and interannual variability of lightning in a global chemical transport model constrained by LIS/OTD satellite data, J. Geophys. Res., 117, D20307, doi:10.1029/2012JD017934, 2012.

Nishino, N., Arey, J., and Atkinson, R.: Formation Yields of Glyoxal and Methylglyoxal from the Gas-Phase $\mathrm{OH}$ RadicalInitiated Reactions of Toluene, Xylenes, and Trimethylbenzenes as a Function of $\mathrm{NO}_{2}$ Concentration, J. Phys. Chem. A, 114, 10140-10147, doi:10.1021/jp105112h, 2010.

Oltmans, S. J., Lefohn, A. S., Harris, J. M., Tarasick, D. W., Thompson, A. M., Wernli, H., Johnson, B. J., Novelli, P. C., Montzka, S. A., Ray, J. D., Patrick, L. C., Sweeney, C., Jefferson, A., Dann, T., Davies, J., Shapiro, M., and Holben, B. N.: Enhanced ozone over western North America from biomass burning in Eurasia during April 2008 as seen in surface and profile observations, Atmos. Environ., 44, 4497-4509, doi:10.1016/j.atmosenv.2010.07.004, 2010. 
Orlando, J. J., Tyndall, G. S., and Calvert, J. G.: Thermal decomposition pathways for peroxyacetyl nitrate (PAN): Implications for atmospheric methyl nitrate levels, Atmos. Environ. Part A. General Topics, 26, 3111-3118, doi:10.1016/0960-1686(92)90468Z, 1992.

Pandey Deolal, S., Staehelin, J., Brunner, D., Cui, J., Steinbacher, M., Zellweger, C., Henne, S., and Vollmer, M. K.: Transport of PAN and $\mathrm{NO}_{\mathrm{y}}$ from different source regions to the Swiss high alpine site Jungfraujoch, Atmos. Envron., 64, 103-115, doi:10.1016/j.atmosenv.2012.08.021, 2013.

Parrish, D. D., Dunlea, E. J., Atlas, E. L., Schauffler, S., Donnelly, S., Stoud, V., Goldstein, A. H., Millet, D. B., McKay, M., Jaffe, D. A., Price, H. U., Hess, P. G., Flocke, F., and Roberts, J. M.: Changes in the photochemical environment of the temperature North Pacific troposphere in response to increased Asian emissions, J. Geophys. Res, 109, doi:10.1029/2004JD004978, 2004.

Paulot, F., Crounse, J. D., Kjaergaard, H. G., Kroll, J. H., Seinfeld, J. H., and Wennberg, P. O.: Isoprene photooxidation: new insights into the production of acids and organic nitrates, Atmos. Chem. Phys., 9, 1479-1501, doi:10.5194/acp-9-1479-2009, 2009a.

Paulot, F., Crounse, J. D., Kjaergaard, H. G., Kürten, A., St. Clair, J. M., Seinfeld, J. H., and Wennberg, P. O.: Unexpected Epoxide Formation in the Gas-Phase Photooxidation of Isoprene, Science, 325, 730-733, doi:10.1126/science.1172910, 2009b.

Paulot, F., Henze, D. K., and Wennberg, P. O.: Impact of the isoprene photochemical cascade on tropical ozone, Atmos. Chem. Phys., 12, 1307-1325, doi:10.5194/acp-12-1307-2012, 2012.

Peeters, J., Nguyen, T. L., and Vereecken, L.: $\mathrm{HO}_{\mathrm{x}}$ radical regeneration in the oxidation of isoprene, Phys. Chem. Chem. Phys., 11, 5935-5939, 2009.

Penkett, S. A. and Brice, K. A.: The spring maximum in photooxidants in the Northern Hemisphere troposphere, Nature, 319, 655-657, 1986.

Pollack, I. B., Ryerson, T. B., Trainer, M., Neuman, J. A., Roberts, J. M., and Parrish, D. D.: Trends in ozone, its precursors, and related secondary oxidation products in Los Angeles, California: A synthesis of measurements from 1960 to 2010, J. Geophys. Res, 118, 5893-5911, doi:10.1002/jgrd.50472, 2013.

Ran, L., Zhao, C., Geng, F., Tie, X., Tang, X., Peng, L., Zhou, G., Yu, Q., Xu, J., and Guenther, A.: Ozone photochemical production in urban Shanghai, China: Analysis based on ground level observations, J. Geophys. Res., 114, D15301, doi:10.1029/2008JD010752, 2009.

Roberts, J. M.: Measurement of the Henry's law coefficient and first order loss rate of PAN in n-octanol, Geophys. Res. Lett., 32, L08803, doi:10.1029/2004g1022327, 2005.

Roberts, J. M.: PAN and Related Compounds, in: Volatile Organic Compounds in the Atmosphere, Blackwell Publishing Ltd, 221268, 2007.

Roberts, J. M. and Bertman, S. B.: The thermal decomposition of peroxyacetic nitric anhydride (PAN) and peroxymethacrylic nitric anhydride (MPAN), Int. J. Chem. Kin., 24, 297-307, doi:10.1002/kin.550240307, 1992.

Roberts, J. M., Tanner, R. L., Newman, L., Bowersox, V. C., Bottenheim, J. W., Anlauf, K. G., Brice, K. A., Parrish, D. D., Fehsenfeld, F. C., Buhr, M. P., Meagher, J. F., and Bailey, E. M.: Relationships between PAN and ozone at sites in eastern North America, J. Geophys. Res, 100, 22821-22830, doi:10.1029/95jd01221, 1995.
Roberts, J. M., Parrish, D. D., Norton, R. B., Bertman, S. B., Holloway, J. S., Trainer, M., Fehsenfeld, F. C., Carroll, M. A., Albercook, G. M., Wang, T., and Forbes, G.: Episodic removal of $\mathrm{NO}_{\mathrm{y}}$ species from the marine boundary layer over the North Atlantic, J. Geophys. Res., 101, 28947-28960, doi:10.1029/96jd02632, 1996.

Roberts, J. M., Williams, J., Baumann, K., Buhr, M. P., Goldan, P. D., Holloway, J., Hübler, G., Kuster, W. C., McKeen, S. A., Ryerson, T. B., Trainer, M., Williams, E. J., Fehsenfeld, F. C., Bertman, S. B., Nouaime, G., Seaver, C., Grodzinsky, G., Rodgers, M., and Young, V. L.: Measurements of PAN, PPN, and MPAN made during the 1994 and 1995 Nashville Intensives of the Southern Oxidant Study: Implications for regional ozone production from biogenic hydrocarbons, J. Geophys. Res, 103, 2247322490, doi:10.1029/98jd01637, 1998.

Roberts, J. M., Flocke, F., Stroud, C. A., Hereid, D., Williams, E., Fehsenfeld, F., Brune, W., Martinez, M., and Harder, H.: Ground-based measurements of peroxycarboxylic nitric anhydrides (PANs) during the 1999 Southern Oxidants Study Nashville Intensive, J. Geophys. Res., 107, ACH 1-1-ACH 1-10, doi:10.1029/2001jd000947, 2002.

Roberts, J. M., Flocke, F., Chen, G., de Gouw, J., Holloway, J. S., Hübler, G., Neuman, J. A., Nicks Jr., D. K.,, Nowak, J. B., Parrish, D. D., Ryerson, T. B., Sueper, D. T., Warneke, C., and Fehsenfeld, F. C.: Measurement of peroxycarboxylic nitric anhydrides (PANs) during the ITCT 2K2 aircraft intensive experiment, J. Geophys. Res., 109, D23S21, doi:10.1029/2004jd004960, 2004.

Roberts, J. M., Marchewka, M., Bertman, S. B., Goldan, P., Kuster, W., de Gouw, J., Warneke, C., Williams, E., Lerner, B., Murphy, P., Apel, E., and Fehsenfeld, F. C.: Analysis of the isoprene chemistry observed during the New England Air Quality Study (NEAQS) 2002 intensive experiment, J. Geophys. Res., 111, D23S12, doi:10.1029/2006JD007570, 2006.

Roiger, A., Aufmhoff, H., Stock, P., Arnold, F., and Schlager, H.: An aircraft-borne chemical ionization - ion trap mass spectrometer (CI-ITMS) for fast PAN and PPN measurements, Atmos. Meas. Tech., 4, 173-188, doi:10.5194/amt-4-173-2011, 2011.

Sander, S. P., Abbatt, J., Barker, J. R., Burkholder, J. B., Friedl, R. R., Golden, D. M., Huie, R. E., Kolb, C. E., Kurylo, M. J., Moortgat, G. K., Orkin, V. L., and Wine, P. H.: Chemical Kinetics and Photochemical Data for Use in Atmospheric Studies, Evaluation No. 17, JPL Publication 10-6, Jet Propulsion Laboratory, Pasedena, http://jpldataeval.jpl.nasa.gov (last access: 3 March 2014), 2011.

Saunders, S. M., Jenkin, M. E., Derwent, R. G., and Pilling, M. J.: Protocol for the development of the Master Chemical Mechanism, MCM v3 (Part A): tropospheric degradation of nonaromatic volatile organic compounds, Atmos. Chem. Phys., 3, 161-180, doi:10.5194/acp-3-161-2003, 2003.

Sauvage, B., Martin, R. V., van Donkelaar, A., Liu, X., Chance, K., L., J., Palmer, P. I., Wu, S., and Fu, T. M.: Remote sensed and in situ constraints on processes affecting tropical tropospheric ozone, Atmos. Chem. Phys., 7, 815-838, doi:10.5194/acp-7-8152007, 2007.

Shepson, P. B., Bottenheim, J. W., Hastie, D. R., and Venkatram, A.: Determination of the relative ozone and PAN deposition velocities at night, Geophys. Res. Lett., 19, 1121-1124, doi:10.1029/92gl01118, 1992. 
Sillman, S. and Samson, P. J.: Impact of temperature on oxidant photochemistry in urban, polluted rural and remote environments, J. Geophys. Res, 100, 11497-11508, doi:10.1029/94jd02146, 1995.

Singh, H. B.: Reactive nitrogen in the troposphere: chemistry and transport of $\mathrm{NO}_{\mathrm{x}}$ and PAN, Environ. Sci. Tech., 21, 320-327, doi:10.1021/es00158a001, 1987.

Singh, H. B. and Hanst, P. L.: Peroxyacetyl nitrate (PAN) in the unpolluted atmosphere: An important reservoir for nitrogen oxides, Geophys. Res. Lett., 8, 941-944, doi:10.1029/GL008i008p00941, 1981.

Singh, H. B., Condon, E., Vedder, J., O’Hara, D., Ridley, B. A., Gandrud, B. W., Shetter, J. D., Salas, L. J., Huebert, B., Hsbler, G., Carroll, M. A., Albritton, D. L., Davis, D. D., Bradshaw, J. D., Sandholm, S. T., Rodgers, M. O., Beck, S. M., Gregory, G. L., and LeBel, P. J.: Peroxyacetyl Nitrate Measurements During CITE 2: Atmospheric Distribution and Precursor Relationships, J. Geophys. Res., 95, 10163-10178, doi:10.1029/JD095iD07p10163, 1990a.

Singh, H. B., Herlth, D., O'Hara, D., Salas, L., Torres, A. L., Gregory, G. L., Sachse, G. W., and Kasting, J. F.: Atmospheric Peroxyacetyl Nitrate Measurements Over the Brazilian Amazon Basin During the Wet Season: Relationships With Nitrogen Oxides and Ozone, J. Geophys. Res., 95, 16945-16954, doi:10.1029/JD095iD10p16945, 1990b.

Singh, H. B., Herlth, D., O'Hara, D., Zahnle, K., Bradshaw, J. D., Sandholm, S. T., Talbot, R., Crutzen, P. J., and Kanakidou, M.: Relationship of Peroxyacetyl Nitrate to Active and Total Odd Nitrogen at Northern High Latitudes: Influence of Reservoir Species on $\mathrm{NO}_{\mathrm{x}}$ and $\mathrm{O}_{3}$, J. Geophys. Res., 97, 16523-16530, doi:10.1029/91jd00890, 1992.

Singh, H. B., Herlth, D., O’Hara, D., Zahnle, K., Bradshaw, J. D., Sandholm, S. T., Talbot, R., Gregory, G. L., Sachse, G. W., Blake, D. R., and Wofsy, S. C.: Summertime distribution of PAN and other reactive nitrogen species in the northern high-latitude atmosphere of eastern Canada, J. Geophys. Res., 99, 1821-1835, doi:10.1029/93JD00946, 1994.

Singh, H. B., Kanakidou, M., Crutzen, P. J., and Jacob, D. J.: High concentrations and photochemical fate of oxygenated hydrocarbons in the global troposphere, Nature, 378, 50-54, 1995.

Singh, H. B., Herlth, D., Kolyer, R., Chatfield, R., Viezee, W., Salas, L. J., Chen, Y., Bradshaw, J. D., Sandholm, S. T., Talbot, R., Gregory, G. L., Anderson, B., Sachse, G. W., Browell, E., Bachmeier, A. S., Blake, D. R., Heikes, B., Jacob, D., and Fuelberg, H. E.: Impact of biomass burning emissions on the composition of the South Atlantic troposphere: Reactive nitrogen and ozone, J. Geophys. Res., 101, 24203-24219, doi:10.1029/96JD01018, 1996a.

Singh, H. B., Herlth, D., Kolyer, R., Salas, L., Bradshaw, J. D., Sandholm, S. T., Davis, D. D., Crawford, J., Kondo, Y., Koike, M., Talbot, R., Gregory, G. L., Sachse, G. W., Browell, E., Blake, D. R., Rowland, F. S., Newell, R., Merrill, J., Heikes, B., Liu, S. C., Crutzen, P. J., and Kanakidou, M.: Reactive nitrogen and ozone over the western Pacific: Distribution, partitioning, and sources, J. Geophys. Res., 101, 1793-1808, doi:10.1029/95JD01029, 1996b.

Singh, H. B., Viezee, W., Chen, Y., Thakur, A. N., Kondo, Y., Talbot, R. W., Gregory, G. L., Sachse, G. W., Blake, D. R., Bradshaw, J. D., Wang, Y., and Jacob, D. J.: Latitudinal distribution of reactive nitrogen in the free troposphere over the Pacific Ocean in late winter/early spring, J. Geophys. Res., 103, 28237-28246, doi:10.1029/98JD01891, 1998.

Singh, H. B., Brune, W. H., Crawford, J. H., Jacob, D. J., and Russell, P. B.: Overview of the summer 2004 Intercontinental Chemical Transport Experiment-North America (INTEX-A), J. Geophys. Res., 111, D24S01, doi:10.1029/2006jd007905, 2006.

Singh, H. B., Salas, L., Herlth, D., Kolyer, R., Czech, E., Avery, M., Crawford, J. H., Pierce, R. B., Sachse, G. W., Blake, D. R., Cohen, R. C., Bertram, T. H., Perring, A., Wooldridge, P. J., Dibb, J., Huey, G., Hudman, R. C., Turquety, S., Emmons, L. K., Flocke, F., Tang, Y., Carmichael, G. R., and Horowitz, L. W.: Reactive nitrogen distribution and partitioning in the North American troposphere and lowermost stratosphere, J. Geophys. Res., 112, D12S04, doi:10.1029/2006JD007664, 2007.

Singh, H. B., Brune, W. H., Crawford, J. H., Flocke, F., and Jacob, D. J.: Chemistry and transport of pollution over the Gulf of Mexico and the Pacific: spring 2006 INTEX-B campaign overview and first results, Atmos. Chem. Phys., 9, 2301-2318, doi:10.5194/acp-9-2301-2009, 2009.

Slusher, D. L., Huey, L. G., Tanner, D. J., Flocke, F. M., and Roberts, J. M.: A thermal dissociation chemical ionization mass spectrometry (TD-CIMS) technique for the simultaneous measurement of peroxyacyl nitrates and dinitrogen pentoxide, J. Geophys. Res., 109, D19315, doi:10.1029/2004JD004670, 2004. Smyth, S. B., Sandholm, S. T., Bradshaw, J. D., Talbot, R. W., Blake, D. R., Blake, N. J., Rowland, F. S., Singh, H. B., Gregory, G. L., Anderson, B. E., Sachse, G. W., Collins, J. E., and Bachmeier, A. S.: Factors influencing the upper free tropospheric distribution of reactive nitrogen over the South Atlantic during the TRACE A experiment, J. Geophys. Res., 101, 24165-24186, doi:10.1029/96jd00224, 1996.

Stewart, D. J., Taylor, C. M., Reeves, C. E., and McQuaid, J. B.: Biogenic nitrogen oxide emissions from soils: impact on $\mathrm{NO}_{\mathrm{x}}$ and ozone over west Africa during AMMA (African Monsoon Multidisciplinary Analysis): observational study, Atmos. Chem. Phys., 8, 2285-2297, doi:10.5194/acp-8-2285-2008, 2008.

Stone, D., Evans, M. J., Walker, H. M., Ingham, T., Vaughan, S., Ouyang, B., Kennedy, O. J., McLeod, M. W., Jones, R. L., Hopkins, J., Punjabi, S., Lidster, R., Hamilton, J. F., Lee, J. D., Lewis, A. C., Carpenter, L. J., Forster, G., Oram, D. E., Reeves, C. E., Bauguitte, S., Morgan, W., Coe, H., Aruffo, E., Dari-Salisburgo, C., Giammaria, F., Di Carlo, P., and Heard, D. E.: Radical chemistry at night: comparisons between observed and modelled $\mathrm{HO}_{\mathrm{x}}, \mathrm{NO}_{3}$ and $\mathrm{N}_{2} \mathrm{O}_{5}$ during the RONOCO project, Atmos. Chem. Phys. Discuss., 13, 95199566, doi:10.5194/acpd-13-9519-2013, 2013.

Stroud, C., Madronich, S., Atlas, E., Cantrell, C., Fried, A., Wert, B., Ridley, B., Eisele, F., Mauldin, L., Shetter, R., Lefer, B., Flocke, F., Weinheimer, A., Coffey, M., Heikes, B., Talbot, R., and Blake, D.: Photochemistry in the Arctic Free Troposphere: Ozone Budget and Its Dependence on Nitrogen Oxides and the Production Rate of Free Radicals, J.of Atmos. Chem., 47, 107138, doi:10.1023/B:JOCH.0000021026.71906.e1, 2004.

Sudo, K., Takahashi, M., and Akimoto, H.: CHASER: A global chemical model of the troposphere 2. Model results and evaluation, J. Geophys. Res, 107, 4586, doi:10.1029/2001jd001114, 2002.

Talbot, R., Dibb, J., Scheuer, E., Seid, G., Russo, R., Sandholm, S., Tan, D., Singh, H., Blake, D., Blake, N., Atlas, E., 
Sachse, G., Jordan, C., and Avery, M.: Reactive nitrogen in Asian continental outflow over the western Pacific: Results from the NASA Transport and Chemical Evolution over the Pacific (TRACE-P) airborne mission, J. Geophys. Res., 108, 8803, doi:10.1029/2002jd003129, 2003.

Talbot, R. W., Dibb, J. E., Scheuer, E. M., Kondo, Y., Koike, M., Singh, H. B., Salas, L. B., Fukui, Y., Ballenthin, J. O., Meads, R. F., Miller, T. M., Hunton, D. E., Viggiano, A. A., Blake, D. R., Blake, N. J., Atlas, E., Flocke, F., Jacob, D. J., and Jaegle, L.: Reactive nitrogen budget during the NASA SONEX Mission, Geophys. Res. Lett., 26, 3057-3060, doi:10.1029/1999GL900589, 1999.

Talbot, R. W., Dibb, J. E., Scheuer, E. M., Bradshaw, J. D., Sandholm, S. T., Singh, H. B., Blake, D. R., Blake, N. J., Atlas, E., and Flocke, F.: Tropospheric reactive odd nitrogen over the South Pacific in austral springtime, J. Geophys. Res., 105, 6681-6694, doi:10.1029/1999JD901114, 2000.

Talukdar, R. K., Burkholder, J. B., Schmoltner, A.-M., Roberts, J. M., Wilson, R. R., and Ravishankara, A. R.: Investigation of the loss processes for peroxyacetyl nitrate in the atmosphere: UV photolysis and reaction with OH, J. Geophys. Res., 100, 1416314173, doi:10.1029/95jd00545, 1995.

Tanimoto, H., Wild, O., Kato, S., Furutani, H., Makide, Y., Komazaki, Y., Hashimoto, S., Tanaka, S., and Akimoto, H.: Seasonal cycles of ozone and oxidized nitrogen species in northeast Asia 2. A model analysis of the roles of chemistry and transport, J. Geophys. Res., 107, 4706, doi:10.1029/2001jd001497, 2002.

Tereszchuk, K. A., Moore, D. P., Harrison, J. J., Boone, C. D., Park, M., Remedios, J. J., Randel, W. J., and Bernath, P. F.: Observations of peroxyacetyl nitrate (PAN) in the upper troposphere by the Atmospheric Chemistry Experiment-Fourier Transform Spectrometer (ACE-FTS), Atmos. Chem. Phys., 13, 5601-5613, doi:10.5194/acp-13-5601-2013, 2013.

Thakur, A. N., Singh, H. B., Mariani, P., Chen, Y., Wang, Y., Jacob, D. J., Brasseur, G., Müller, J. F., and Lawrence, M.: Distribution of reactive nitrogen species in the remote free troposphere: data and model comparisons, Atmos. Environ., 33, 1403-1422, doi:10.1016/s1352-2310(98)00281-7, 1999.

Thornton, J. A., Jaegle, L., and McNeill, V. F.: Assessing known pathways for $\mathrm{HO}_{2}$ loss in aqueous atmospheric aerosols: Regional and global impacts on tropospheric oxidants, J. Geophys. Res., 113, doi:10.1029/2007JD009236, 2008.

Tie, X., Zhang, R., Brasseur, G., Emmons, L., and Lei, W.: Effects of lightning on reactive nitrogen and nitrogen reservoir species in the troposphere, J. Geophys. Res., 106, 3167-3178, doi:10.1029/2000jd900565, 2001.

Turquety, S., Logan, J. A., Jacob, D. J., Hudman, R. C., Leung, F. Y., Heald, C. L., Yantosca, R. M., Wu, S., Emmons, L. K., Edwards, D. P., and Sachse, G. W.: Inventory of boreal fire emissions for North America in 2004: Importance of peat burning and pyroconvective injection, J. Geophys. Res., 112, D12S03, doi:10.1029/2006JD007281, 2007.

Tyndall, G. S., Cox, R. A., Granier, C., Lesclaux, R., Moortgat, G. K., Pilling, M. J., Ravishankara, A. R., and Wallington, T. J.: Atmospheric chemistry of small organic peroxy radicals, J. Geophys. Res, 106, 12157-12182, doi:10.1029/2000jd900746, 2001.

Val Martin, M., Honrath, R. E., Owen, R. C., and Li, Q. B.: Seasonal variation of nitrogen oxides in the central North At- lantic lower free troposphere, J. Geophys. Res, 113, D17307, doi:10.1029/2007jd009688, 2008.

Val Martin, M., Logan, J. A., Kahn, R. A., Leung, F. Y., Nelson, D. L., and Diner, D. J.: Smoke injection heights from fires in North America: analysis of 5 years of satellite observations, Atmos. Chem. Phys., 10, 1491-1510, doi:10.5194/acp-10-14912010, 2010.

van der A, R. J., Eskes, H. J., Boersma, K. F., van Noije, T. P. C., Van Roozendael, M., De Smedt, I., Peters, D. H. M. U., and Meijer, E. W.: Trends, seasonal variability and dominant $\mathrm{NO}_{\mathrm{X}}$ source derived from a ten year record of $\mathrm{NO}_{2}$ measured from space, J. Geophys. Res., 113, D04302, doi:10.1029/2007jd009021, 2008.

van der Werf, G. R., Randerson, J. T., Giglio, L., Collatz, G. J., Mu, M., Kasibhatla, P. S., Morton, D. C., DeFries, R. S., Jin, Y., and van Leeuwen, T. T.: Global fire emissions and the contribution of deforestation, savanna, forest, agricultural, and peat fires (19972009), Atmos. Chem. Phys., 10, 11707-11735, doi:10.5194/acp10-11707-2010, 2010.

van Donkelaar, A., Martin, R. V., Leaitch, W. R., Macdonald, A. M., Walker, T. W., Streets, D. G., Zhang, Q., Dunlea, E. J., Jimenez, J. L., Dibb, J. E., Huey, L. G., Weber, R., and Andreae, M. O.: Analysis of aircraft and satellite measurements from the Intercontinental Chemical Transport Experiment (INTEX-B) to quantify long-range transport of East Asian sulfur to Canada, Atmos. Chem. Phys., 8, 2999-3014, doi:10.5194/acp-8-2999-2008, 2008.

van het Bolscher, M., Pereira, J., Spessa, A., Dalsoren, S., van Nojie, T., and Szopa, S.: REanalysis of the TROpospheric chemical composition over the past 40 years: A long-term global modeling study of tropospheric chemistry, Max Plank Inst. for Meteorology, Hamburg, Germany, 77, 2008.

Vestreng, V., and Klein, H.: Emission data reported to UNECE/EMEP: Quality assurance and trend analysis \& presentation of WebDab, Norwegian Meteorological Institute, Oslo, Norway, 2002.

Villalta, P. W., Lovejoy, E. R., and Hanson, D. R.: Reaction probability of peroxyacetyl radical on aqueous surfaces, Geophys. Res. Lett., 23, 1765-1768, doi:10.1029/96GL01286, 1996.

Vivchar, A.: Wildfires in Russia in 2000-2008: estimates of burnt areas using the satellite MODIS MCD45 data, Remote Sens. Lett., 2, 81-90, doi:10.1080/01431161.2010.499138, 2010.

von Kuhlmann, R., Lawrence, M. G., Crutzen, P. J., and Rasch, P. J.: A model for studies of tropospheric ozone and nonmethane hydrocarbons: Model evaluation of ozone-related species, J. Geophys. Res, 108, 4729, doi:10.1029/2002jd003348, 2003.

von Kuhlmann, R., Lawrence, M. G., Pöschl, U., and Crutzen, P. J.: Sensitivities in global scale modeling of isoprene, Atmos. Chem. Phys., 4, 1-17, doi:10.5194/acp-4-1-2004, 2004.

Walker, T. W., Jones, D. B. A., Parrington, M., Henze, D. K., Murray, L. T., Bottenheim, J. W., Anlauf, K., Worden, J. R., Bowman, K. W., Shim, C., Singh, K., Kopacz, M., Tarasick, D. W., Davies, J., von der Gathen, P., Thompson, A. M., and Carouge, C. C.: Impacts of midlatitude precursor emissions and local photochemistry on ozone abundances in the Arctic, J. Geophys. Res., 117, D01305, doi:10.1029/2011JD016370, 2012.

Wallington, T. J., Andino, J. M., Ball, J. C., and Japar, S. M.: Fourier transform infrared studies of the reaction of $\mathrm{Cl}$ atoms with $\mathrm{PAN}, \mathrm{PPN}, \mathrm{CH}_{3} \mathrm{OOH}, \mathrm{HCOOH}, \mathrm{CH}_{3} \mathrm{COCH}_{3}$ and 
$\mathrm{CH}_{3} \mathrm{COC}_{2} \mathrm{H}_{5}$ at $295 \pm 2 \mathrm{~K}$, J. Atmos. Chem., 10, 301-313, doi:10.1007/bf00053865, 1990.

Wang, S., Wu, D., Wang, X.-M., Fung, J. C.-H., and Yu, J. Z.: Relative contributions of secondary organic aerosol formation from toluene, xylenes, isoprene, and monoterpenes in Hong Kong and Guangzhou in the Pearl River Delta, China: an emissionbased box modeling study, J. Geophys. Res, 118, 507-519, doi:10.1029/2012JD017985, 2013.

Wang, X.-m., Sheng, G.-y., Fu, J.-M., Chan, C.-y., Lee, S.-C., Chan, L. Y., and Wang, Z.-s.: Urban roadside aromatic hydrocarbons in three cities of the Pearl River Delta, People's Republic of China, Atmos. Environ., 36, 5141-5148, doi:10.1016/S13522310(02)00640-4, 2002.

Wang, Y. X., McElroy, M. B., Jacob, D. J., and Yantosca, R. M.: A nested grid formulation for chemical transport over Asia: Applications to CO, Journal of Geophysical Research: Atmospheres, 109, D22307, doi:10.1029/2004JD005237, 2004.

Wang, Y., Jacob, D. J., and Logan, J. A.: Global simulation of tropospheric $\mathrm{O}_{3}-\mathrm{NO}_{\mathrm{x}}$-hydrocarbon chemistry: 3. Origin of tropospheric ozone and effects of nonmethane hydrocarbons, J. Geophys. Res, 103, 10757-10767, doi:10.1029/98JD00156, 1998a.

Wang, Y., Logan, J. A., and Jacob, D. J.: Global simulation of tropospheric $\mathrm{O}_{3}-\mathrm{NO}_{\mathrm{x}}$-hydrocarbon chemistry 2 . Model evaluation and global ozone budget, J. Geophys. Res., 103, 10727-10755, doi:10.1029/98jd00157, 1998b.

Wang, Y., Ridley, B., Fried, A., Cantrell, C., Davis, D., Chen, G., Snow, J., Heikes, B., Talbot, R., Dibb, J., Flocke, F., Weinheimer, A., Blake, N., Blake, D., Shetter, R., Lefer, B., Atlas, E., Coffey, M., Walega, J., and Wert, B.: Springtime photochemistry at northern mid and high latitudes, J. Geophys. Res., 108, 8358, doi:10.1029/2002jd002227, 2003.

Warneke, C., Holzinger, R., Hansel, A., Jordan, A., Lindinger, W., Pöschl, U., Williams, J., Hoor, P., Fischer, H., Crutzen, P. J., Scheeren, H. A., and Lelieveld, J.: Isoprene and Its Oxidation Products Methyl Vinyl Ketone, Methacrolein, and Isoprene Related Peroxides Measured Online over the Tropical Rain Forest of Surinam in March 1998, J. Atmos. Chem., 38, 167-185, doi:10.1023/a:1006326802432, 2001.

Warneke, C., Bahreini, R., Brioude, J., Brock, C. A., de Gouw, J. A., Fahey, D. W., Froyd, K. D., Holloway, J. S., Middlebrook, A., Miller, L., Montzka, S., Murphy, D. M., Peischl, J., Ryerson, T. B., Schwarz, J. P., Spackman, J. R., and Veres, P.: Biomass burning in Siberia and Kazakhstan as an important source for haze over the Alaskan Arctic in April 2008, Geophys. Res. Lett., 36, L02813, doi:10.1029/2008GL036194, 2009.

Warneke, C., Froyd, K. D., Brioude, J., Bahreini, R., Brock, C. A., Cozic, J., de Gouw, J. A., Fahey, D. W., Ferrare, R., Holloway, J. S., Middlebrook, A. M., Miller, L., Montzka, S., Schwarz, J. P., Sodemann, H., Spackman, J. R., and Stohl, A.: An important contribution to springtime Arctic aerosol from biomass burning in Russia, Geophys. Res. Lett., 37, L01801, doi:10.1029/2009g1041816, 2010.

Warneke, C., Roberts, J. M., Veres, P., Gilman, J., Kuster, W. C., Burling, I., Yokelson, R., and de Gouw, J. A.: VOC identification and inter-comparison from laboratory biomass burning using PTR-MS and PIT-MS, Int. J. Mass Spectrom., 303, 6-14, doi:10.1016/j.ijms.2010.12.002, 2011.
Wesely, M. L.: Parameterization of surface resistances to gaseous dry deposition in regional-scale numerical models, Atmos. Environ., 23, 1293-1304, doi:10.1016/0004-6981(89)90153-4, 1989.

Whalley, L. K., Lewis, A. C., McQuaid, J. B., Purvis, R. M., Lee, J. D., Stemmler, K., Zellweger, C., and Ridgeon, P.: Two highspeed, portable GC systems designed for the measurement of non-methane hydrocarbons and PAN: Results from the Jungfraujoch High Altitude Observatory, J. Environ. Mon., 6, 234-241, 2004.

Wiedinmyer, C., Akagi, S. K., Yokelson, R. J., Emmons, L. K., AlSaadi, J. A., Orlando, J. J., and Soja, A. J.: The Fire INventory from NCAR (FINN): a high resolution global model to estimate the emissions from open burning, Geosci. Model Dev., 4, 625641, doi:10.5194/gmd-4-625-2011, 2011.

Wiegele, A., Glatthor, N., Höpfner, M., Grabowski, U., Kellmann, S., Linden, A., Stiller, G., and von Clarmann, T.: Global distributions of $\mathrm{C}_{2} \mathrm{H}_{6}, \mathrm{C}_{2} \mathrm{H}_{2}, \mathrm{HCN}$, and PAN retrieved from MIPAS reduced spectral resolution measurements, Atmos. Meas. Tech., 5, 723-734, doi:10.5194/amt-5-723-2012, 2012.

Williams, J. E., van Velthoven, P. F. J., and Brenninkmeijer, C. A. M.: Quantifying the uncertainty in simulating global tropospheric composition due to the variability in global emission estimates of Biogenic Volatile Organic Compounds, Atmos. Chem. Phys., 13, 2857-2891, doi:10.5194/acp-13-2857-2013, 2013.

Wolfe, G. M., Thornton, J. A., McNeill, V. F., Jaffe, D. A., Reidmiller, D., Chand, D., Smith, J., Swartzendruber, P., Flocke, F., and Zheng, W.: Influence of trans-Pacific pollution transport on acyl peroxy nitrate abundances and speciation at Mount Bachelor Observatory during INTEX-B, Atmos. Chem. Phys., 7, 53095325, doi:10.5194/acp-7-5309-2007, 2007.

Worthy, D. E. J., Trivett, N. B. A., Hopper, J. F., and Bottenheim, J. W.: Analysis of long-range transport events at Alert, Northwest Territories, during the Polar Sunrise Experiment, J. Geophys. Res, 99, 25329-25344, 1994.

Xiao, Y., Logan, J. A., Jacob, D. J., Hudman, R. C., Yantosca, R., and Blake, D. R.: Global budget of ethane and regional constraints on U.S. sources, J. Geophys. Res., 113, D21306, doi:10.1029/2007jd009415, 2008.

Xue, L. K., Wang, T., Zhang, J. M., Zhang, X. C., Deliger, Poon, C. N., Ding, A. J., Zhou, X. H., Wu, W. S., Tang, J., Zhang, Q. Z., and Wang, W. X.: Source of surface ozone and reactive nitrogen speciation at Mount Waliguan in western China: New insights from the 2006 summer study, J. Geophys. Res., 116, D07306, doi:10.1029/2010jd014735, 2011.

Yienger, J. J. and Levy II, H.: Empirical model of global soilbiogenic $\mathrm{NO}_{\mathrm{x}}$ emissions, J. Geophys. Res., 100, 11447-11464, doi:10.1029/95jd00370, 1995.

Zanis, P., Monks, P. S., Green, T. J., Schuepbach, E., Carpenter, L. J., Mills, G. P., Rickard, A. R., Brough, N., and Penkett, S. A.: Seasonal variation of peroxy radicals in the lower free troposphere based on observations from the FREE Tropospheric EXperiments in the Swiss Alps, Geophys. Res. Lett., 30, 1497, doi:10.1029/2003GL017122, 2003.

Zanis, P., Ganser, A., Zellweger, C., Henne, S., Steinbacher, M., and Staehelin, J.: Seasonal variability of measured ozone production efficiencies in the lower free troposphere of Central Europe, Atmos. Chem. Phys., 7, 223-236, doi:10.5194/acp-7-223-2007, 2007. 
Zellweger, C., Ammann, M., Buchmann, B., Hofer, P., Lugauer, M., Rüttimann, R., Streit, N., Weingartner, E., and Baltensperger, U.: Summertime $\mathrm{NO}_{\mathrm{y}}$ speciation at the Jungfraujoch, $3580 \mathrm{~m}$ above sea level, Switzerland, J. Geophys. Res., 105, 6655-6667, doi:10.1029/1999jd901126, 2000.

Zhang, J., Wang, T., Chameides, W. L., Cardelino, C., Kwok, J., Blake, D. R., Ding, A., and So, K. L.: Ozone production and hydrocarbon reactivity in Hong Kong, Southern China, Atmos. Chem. Phys., 7, 557-573, doi:10.5194/acp-7-557-2007, 2007a.

Zhang, L., Jacob, D. J., Boersma, K. F., Jaffe, D. A., Olson, J. R., Bowman, K. W., Worden, J. R., Thompson, A. M., Avery, M. A., Cohen, R. C., Dibb, J. E., Flock, F. M., Fuelberg, H. E., Huey, L. G., McMillan, W. W., Singh, H. B., and Weinheimer, A. J.: Transpacific transport of ozone pollution and the effect of recent Asian emission increases on air quality in North America: an integrated analysis using satellite, aircraft, ozonesonde, and surface observations, Atmos. Chem. Phys., 8, 6117-6136, doi:10.5194/acp-8-6117-2008, 2008.
Zhang, Q., Streets, D. G., He, K., Wang, Y., Richter, A., Burrows, J. P., Uno, I., Jang, C. J., Chen, D., Yao, Z., and Lei, Y.: $\mathrm{NO}_{\mathrm{X}}$ emission trends for China, 1995-2004: The view from the ground and the view from space, J. Geophys. Res., 112, D22306, doi:10.1029/2007jd008684, 2007b.

Zhang, Q., Streets, D. G., Carmichael, G. R., He, K. B., Huo, H., Kannari, A., Klimont, Z., Park, I. S., Reddy, S., Fu, J. S., Chen, D., Duan, L., Lei, Y., Wang, L. T., and Yao, Z. L.: Asian emissions in 2006 for the NASA INTEX-B mission, Atmos. Chem. Phys., 9, 5131-5153, doi:10.5194/acp-9-5131-2009, 2009.

Zheng, W., Flocke, F. M., Tyndall, G. S., Swanson, A., Orlando, J. J., Roberts, J. M., Huey, L. G., and Tanner, D. J.: Characterization of a thermal decomposition chemical ionization mass spectrometer for the measurement of peroxy acyl nitrates (PANs) in the atmosphere, Atmos. Chem. Phys., 11, 6529-6547, doi:10.5194/acp-11-6529-2011, 2011. 